\title{
In Vitro Assessment of Uptake and Lysosomal Sequestration of Respiratory Drugs in Alveolar Macrophage Cell Line NR8383
}

\author{
Ayşe Ufuk' • Graham Somers ${ }^{2} \cdot$ J. Brian Houston ' • Aleksandra Galetin '
}

Received: 25 March 2015 / Accepted: 7 July 2015 / Published online: 30 July 2015

(C) The Author(s) 2015

\section{ABSTRACT}

Purpose To assess accumulation and lysosomal sequestration of 9 drugs used in respiratory indications (plus imipramine as positive control) in the alveolar macrophage (AM) cell line NR8383.

Methods For all drugs, uptake at $5 \mu \mathrm{M}$ was investigated at 37 and $4{ }^{\circ} \mathrm{C}$ to delineate active uptake and passive diffusion processes. Accumulation of basic clarithromycin, formoterol and imipramine was also assessed over $0.1-100 \mu \mathrm{M}$ concentration range. Lysosomal sequestration was investigated using ammonium chloride $\left(\mathrm{NH}_{4} \mathrm{Cl}\right)$, monensin and nigericin. Impact of lysosomal sequestration on clarithromycin accumulation kinetics was investigated.

Results Both cell-to-medium concentration ratio $\left(\mathrm{K}_{\mathrm{p}}\right)$ and uptake clearance $\left(\mathrm{CL}_{\text {uptake }}\right)$ ranged $>400$-fold for the drugs investigated. The greatest $\mathrm{K}_{\mathrm{p}}$ was observed for imipramine (391) and clarithromycin (82), in contrast to no accumulation seen for terbutaline. A concentration-dependent accumulation was evident for the basic drugs investigated. Imipramine and clarithromycin $\mathrm{K}_{\mathrm{p}}$ and $\mathrm{CL}_{\text {uptake }}$ were reduced by 59 $85 \%$ in the presence of $\mathrm{NH}_{4} \mathrm{Cl}$ and monensin/nigericin, indicating lysosomal accumulation, whereas lysosomal sequestration was not pronounced for the other 8 respiratory drugs. Clarithromycin uptake rate was altered by $\mathrm{NH}_{4} \mathrm{Cl}$,

Electronic supplementary material The online version of this article (doi: | 0. I007/s | | 095-0 | 5- | 753-8) contains supplementary material, which is available to authorized users.

Aleksandra Galetin

Aleksandra.Galetin@manchester.ac.uk

Centre for Applied Pharmacokinetic Research, Manchester Pharmacy School, The University of Manchester, Stopford Building, Oxford Road, Manchester MI3 9PT, UK

2 GlaxoSmithKline, Medicines Research Centre, Stevenage, UK highlighting the impact of subcellular distribution on accumulation kinetics.

Conclusions This study provides novel evidence of the utility of NR8383 for investigating accumulation and lysosomal sequestration of respiratory drugs in AMs.

KEY WORDS alveolar macrophages · lysosomal sequestration · NR8383 · respiratory drugs

$\begin{array}{ll}\text { ABBREVIATIONS } \\ \text { ABT } & \text { 1-aminobenzotriazole } \\ \text { AM(s) } & \text { Alveolar macrophage(s) } \\ \text { BSA } & \text { Bovine serum albumin } \\ \text { CAD } & \text { Cationic amphiphilic drug } \\ \text { CGM } & \text { Complete growth medium } \\ \text { CL }_{\text {diff }} & \text { Passive diffusion clearance } \\ \text { CL }_{\text {uptake }} & \text { Total uptake clearance } \\ \text { DPBS } & \text { Dulbecco's phosphate buffered saline } \\ \mathrm{K}_{\mathrm{p}} & \text { Cell-to-medium concentration } \\ & \text { ratio } \\ \mathrm{LC}-\mathrm{MS} / \mathrm{MS} & \text { Liquid chromatography with } \\ & \text { tandem mass spectrometry } \\ \mathrm{LTR} & \text { LysoTracker Red } \\ \mathrm{NH}{ }_{4} \mathrm{Cl} & \text { Ammonium chloride }\end{array}$

\section{INTRODUCTION}

Understanding drug disposition in the lungs remains a challenging task in the development of new medications for asthma, chronic obstructive pulmonary disease and bacterial infections (1). Several factors may affect the therapeutic efficacy of inhaled drugs including delivery devices, formulation and dose, drug physicochemical properties, metabolism and lung clearance mechanisms and disease state (2-4). Phagocytic alveolar macrophages (AMs) represent important components 
of clearance mechanism of drugs from the respiratory airways. While accumulation of certain drugs in AMs is required for their therapeutic effect (e.g., macrolide antibiotics), this process could affect the efficacy and duration of drugs targeting submucosal compartments such as $\beta_{2}$-agonists and antimuscarinics. In addition, pronounced accumulation of basic drugs (often cationic amphiphilic drugs, i.e., CADs) in lysosomes of AMs may lead to drug induced phospholipidosis and the presence of foamy macrophages in the airways (5). Lysosomal sequestration of CADs has been attributed to the $\mathrm{pH}$ differences between cytosol $(\mathrm{pH}=7.2)$ and lysosomes, as the most acidic cell organelles $(\mathrm{pH}=4.7-4.8)$ (6). The unionised form of basic drugs can rapidly diffuse into lysosomes where they become predominantly ionised and 'trapped' as a result of the limited permeability of lysosomal membrane to ionised drugs. Lysosomal sequestration may lead to significantly higher intracellular drug concentrations which may have important therapeutic or toxicological consequences $(7,8)$. In addition, drug-drug interactions involving lysosomotropic drugs have been proposed as an important implication of lysosomal drug sequestration $(8,9)$. In vitro methods employed to investigate lysosomal sequestration include both direct approaches such as measuring drug concentrations in isolated lysosomes following homogenisation (10-12) and indirect methods based on the use of chemical agents to abolish lysosome-cytosol $\mathrm{pH}$ gradient (e.g., ammonium chloride $\left(\mathrm{NH}_{4} \mathrm{Cl}\right)$, monensin and nigericin) (12-14). Reduction in drug accumulation in the presence of these indirect agents relative to control provides the extent of lysosomal accumulation (reference studies provided in the Supplementary Material, Table S1). In addition, assays involving the use of lysosome specific fluorescent dye, Lyso Tracker Red (LTR), have also been reported for semiquantitative investigation of lysosomal drug sequestration (14-16).
NR8383 is an AM cell line originally derived by bronchoalveolar lavage procedure of an adult male Sprague-Dawley rat; this cell line was shown to exhibit several characteristics and functions of freshly isolated rat AMs $(17,18)$. Previous uptake studies in NR8383 focused on a single drug per study and mainly on antibiotics used for respiratory infections $(19,20)$. To date, there are no studies investigating the accumulation in AMs of a substantial number of respiratory drugs targeting other disease areas including asthma and chronic obstructive pulmonary disease.

The aim of this study was to systematically assess the extent of intracellular accumulation in AMs and the contribution of lysosomal sequestration for nine selected drugs. All drugs in the dataset are designed or used in respiratory indications, cover a wide range of physicochemical properties and have limited in vitro accumulation data reported in AMs. The selected drugs and their respective physicochemical properties are summarised in Table I, together with the location of the drug target (intra- or extracellular). The corresponding chemical structures are shown in the Supplementary Material Figure S1. Drug uptake into AMs was investigated at a single substrate concentration at $37^{\circ} \mathrm{C}$ and $4^{\circ} \mathrm{C}$ to determine the dependence of cellular accumulation on active uptake and passive diffusion processes, respectively. In addition, the accumulation of a number of selected drugs in AMs was investigated over a range of substrate concentrations. In order to assess its contribution to uptake into AMs, lysosomal sequestration of the drugs was investigated in the presence of agents that abolish lysosome-cytosol $\mathrm{pH}$ gradient; lysosomotropic drug imipramine was included as a positive control in the studies. Cell-to-medium concentration ratio $\left(\mathrm{K}_{\mathrm{p}}\right)$ was determined in the presence and absence of these agents to evaluate the extent of lysosomal accumulation. The in vitro data were supported by staining of the cells with LTR under control

Table I Physicochemical Properties of I 0 Drugs Selected for the Investigation of Drug Uptake and Lysosomal Sequestration in NR8383 Cell Line

\begin{tabular}{|c|c|c|c|c|c|c|c|c|}
\hline Drug & Target & $\log P$ & $\log _{7.4}$ & $\mathrm{pK}_{\mathrm{a} \_\mathrm{a}}$ & $\mathrm{pK}_{\mathrm{a}-\mathrm{b}}$ & $\operatorname{PSA}\left(\AA^{2}\right)^{\mathrm{a}}$ & Acid-base Property & References \\
\hline Clarithromycin $^{\mathrm{c}}$ & Intracellular bacteria & 3.16 & 1.57 & - & 8.99 & 183 & Base & $(21)$ \\
\hline Imipramine & Extracellular serotonin receptor & 4.80 & 2.38 & - & 9.50 & 6.50 & Base & $(22-24)$ \\
\hline Formoterol $^{\mathrm{d}, \mathrm{e}}$ & Extracellular $\beta_{2}$-receptor & $1.99^{\mathrm{a}}$ & 2.60 & $10.1,11.8^{a}$ & $8.14^{a}$ & 90.8 & Base & $(25)$ \\
\hline Fenoterol $^{d}$ & Extracellular $\beta_{2}$-receptor & $1.09^{\mathrm{a}}$ & 0.74 & $9.40,10.1^{a}$ & $8.25^{\mathrm{a}}$ & 93.0 & Base & (25) \\
\hline Terbutaline $^{d}$ & Extracellular $\beta_{2}$-receptor & 0.90 & $-1.50^{b}$ & $8.60,11.0$ & 9.90 & 72.7 & Base & $(26-28)$ \\
\hline Budesonide $^{d}$ & Extracellular glucocorticoid receptor & $2.47^{\mathrm{a}}$ & $2.47^{\mathrm{a}}$ & $\mathrm{n} / \mathrm{a}$ & & 93.1 & Neutral & \\
\hline Tiotropium bromide $^{d}$ & Extracellular muscarinic receptor & $-1.23^{a}$ & $-1.49^{a}$ & $\mathrm{n} / \mathrm{a}$ & & 59.1 & Permanently cationic & \\
\hline Ipratropium bromide ${ }^{d}$ & Extracellular muscarinic receptor & $-1.20^{a}$ & $-1.75^{a}$ & $n / a$ & & 46.5 & Permanently cationic & \\
\hline Rifampicin $^{c}$ & Intracellular bacteria & $2.54^{\mathrm{a}}$ & 0.3 & 1.7 & 6.70 & 217 & Zwitterion & $(29,30)$ \\
\hline Ciprofloxacin ${ }^{c}$ & Intracellular bacteria & 0.28 & -1.11 & 6.30 & 8.60 & 74.6 & Zwitterion & $(24,26)$ \\
\hline
\end{tabular}

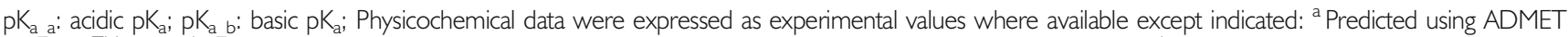
Predictor $^{T M}$ V7.0; ${ }^{b}$ Average value of two studies $(27,28)$; Respiratory indications are ${ }^{c}$ intracellular infections and ${ }^{d}$ COPD and asthma; ${ }^{e}$ Predicted LogP is expected to be higher than indicated, as the measured $\log \mathrm{D}_{7.4}$ is higher than this value 
conditions and in the presence of a number of basic drugs and the above mentioned chemical agents. Recommendations of the application of NR8383 for the assessment of accumulation and lysosomal sequestration of respiratory drugs are provided.

\section{MATERIALS AND METHODS}

\section{Chemicals and Reagents}

1-Aminobenzotriazole, ammonium chloride, ciprofoxacin, clarithromycin, dimethyl sulphoxide, Imipramine, lactate dehydrogenase activity assay kit, monensin sodium salt, nigericin sodium salt, trypan blue $0.4 \%$ and verapamil hydrochloride were all from Sigma Aldrich Ltd., Dorset, UK. Budesonide, ipratropium bromide, fenoterol, formoterol, terbutaline and tiotropium bromide were all supplied by GlaxoSmithKline, UK. Chloroform and formaldehyde $37-41 \%$ were from Fisher Scientific, Loughborough, UK. Further chemicals include diazepam (Tocris Bioscience, Bristol, UK), methanol (VWR, UK), midazolam (Hoffman La Roche, Switzerland), Pierce BCA protein assay kit (Thermo Scientific, Loughborough, UK) and Lysotracker ${ }^{\circledR}$ Red DND-99 (Life Technologies, Paisley, UK). Reagents include bovine serum albumin and penicillin-streptomycin (Sigma Aldrich Ltd., Dorset, UK), collagen Type I rat tail (BD Biosciences, Oxford, UK), Dulbecco's phosphate buffered saline and heat-inactivated foetal bovine serum (Life Techonolgies, Paisley, UK) and Kaighn's modification of Ham's F12 (Ham's F12K) medium (American Tissue Culture Collection (ATCG), Mannasas, VA, USA).

\section{NR8383 Cell Culture and Maintenance}

The NR8383 cell line (CRL-2192) was purchased from ATCC, Mannasas, VA, USA. Cells were grown in Ham's F12K medium with $2 \mathrm{mM}$ glutamine and $1.5 \mathrm{~g} / \mathrm{L}$ sodium bicarbonate which was further supplemented with $15 \%$ heat-inactivated foetal bovine serum and 100 units/mL penicillin- $100 \mu \mathrm{g} / \mathrm{mL}$ streptomycin to make complete growth medium (CGM). Cells, which were present as both floating and attached cell populations, were routinely maintained in tissue culture flasks. CGM was changed twice per week and involved removal of the floating cells from flasks, rapid addition of fresh CGM into the flasks to maintain adherent cells in medium and re-suspension of floating cells in CGM to be returned into flasks. The latter was performed following centrifugation of the cells at $142 \mathrm{~g}$ for $5 \mathrm{~min}$ (Eppendorf Centrifuge 5804, Cambridge, UK) at room temperature. Upon $\sim 70 \%$ confluency was reached, cells were passaged by gentle scraping of the loosely attached cells into the existing culture medium. Following centrifugation at aforementioned conditions, cell pellet was gently re-suspended in $1 \mathrm{~mL}$ of CGM previously maintained at $37^{\circ} \mathrm{C}$ and seeded into new flasks at $2 \times 10^{5}$ or $3.5 \times 10^{5}$ cells per $\mathrm{mL}$. Cell count and viability were assessed with trypan blue exclusion method using a haemocytometer under the light microscope (Olympus CK2, Olympus Optical Co., Japan). Cells were maintained by incubation at $37^{\circ} \mathrm{C}, 5 \% \mathrm{CO}_{2}$ in a humidified atmosphere. Only cells with passage number up to 25 were used to ensure consistency in the cell line morphology.

\section{Drug Uptake in NR8383}

The cellular uptake method was adapted from Ménochet et al. (2012) (31) and optimised for NR8383, as outlined herein. The studies were carried out in a 24-well plate format and the in vitro conditions were optimised in terms of cell detachment method from culture flasks, coating type of 24-well plates, seeding density, culturing time and drug incubation time points. Briefly, for cell detachment, gentle scraping versus $\mathrm{Mg}^{2+}-\mathrm{Ca}^{2+}$ free DPBS treatment of cells in culture flasks were tested. Considering the semi-adherent nature of AMs, cell seeding into non-coated, collagen-I and poly-D-lysine coated 24-well plates was investigated for cell attachment, distribution in the wells and detachment following DPBS washes during the uptake experiments. In addition, seeding densities of 0.36 and $0.72 \times 10^{6}$ cells per well were assessed with respect to cell attachment, confluency following culture (plating efficiency) and potential cell detachment following DPBS washes. Culturing time ranging from 4 to $24 \mathrm{~h}$ was investigated for optimal cell attachment before carrying out uptake experiments. Uptake rate and $\mathrm{K}_{\mathrm{p}}$ data were normalised by cell number determined indirectly by measuring the amount of protein in samples by bicinchoninic acid (BCA) protein assay (Thermo Scientific, Loughborough, UK). Following the optimisation, detachment of NR8383 from cell culture flasks was performed by gentle scraping prior to cell counting and seeding into collagen-I coated 24-well plates at $0.5 \times 10^{6}$ cells per well. Cells were cultured for $16 \mathrm{~h}$ at $37^{\circ} \mathrm{C}, 5 \% \mathrm{CO}_{2}\left(\mathrm{CO}_{2}\right.$ incubator, MCO-17AIC, Sanyo Biomedical, Loughborough, UK) before uptake studies performed over 1 to $10 \mathrm{~min}$ period. The details of method optimisation outlined above can be found in the Supplementary Material, Figure S2.

Initially, uptake experiments in NR8383 were carried out for all drugs at single substrate concentration of $5 \mu \mathrm{M}$ at 37 and $4^{\circ} \mathrm{C}$ in order to delineate contribution of active uptake and passive diffusion processes. The drug uptake in NR8383 corresponding to these conditions was described by total uptake $\left(\mathrm{CL}_{\text {uptake }}\right)$ and passive diffusion $\left(\mathrm{CL}_{\text {diff }}\right)$ clearance terms, respectively. For a subset of selected drugs, accumulation was assessed over a range of drug concentrations $(0.1-100 \mu \mathrm{M}$ for imipramine, $1-100 \mu \mathrm{M}$ for formoterol and clarithromycin) at $37^{\circ} \mathrm{C}$. In addition, clarithromycin uptake kinetics was evaluated over this concentration range. Substrate solutions were prepared by dilution of the stock solutions in DPBS resulting 
in final DMSO content $<1 \%$. Uptake studies were performed in the presence of $1 \mathrm{mM} \mathrm{ABT}$, a nonspecific $\mathrm{P} 450$ inhibitor, in order to avoid any potential impact of phase I metabolism. Currently there is no evidence of the presence of any conjugation enzymes in this cell line. Following microscopy, the CGM was removed, cells were washed twice with $800 \mu \mathrm{L}$ of either pre-warmed or ice-cold DPBS (for experiments at 37 and $4^{\circ} \mathrm{C}$, respectively) and pre-incubation with $500 \mu \mathrm{L}$ of prewarmed or ice-cold ABT/DPBS was carried out for $20 \mathrm{~min}$. Where ABT pre-treatment was not necessary, cell monolayers were treated with $500 \mu \mathrm{L}$ of DPBS only. Once pre-incubation buffer was removed from the cell monolayers, incubations were started by addition of $400 \mu \mathrm{L}$ of substrate solution (prewarmed or ice-cold) in each well. Each substrate was incubated with the cells for 1, 2, 5 and 10 min and each time point at $37^{\circ} \mathrm{C}$ and $4^{\circ} \mathrm{C}$. For $37^{\circ} \mathrm{C}$ experiments, incubation was carried out on a dry heater block maintained at $37^{\circ} \mathrm{C}$ throughout the experiment (Tecam Dri-block DB-3, Tecam, Princeton, NJ) and for $4^{\circ} \mathrm{C}$ experiments, the procedure was carried out on ice. Incubation with substrate was stopped by removal of the media with drug solution and washing the monolayers three times with $800 \mu \mathrm{L}$ ice-cold DPBS. The back-diffusion of the drug from the cell into the medium was considered to be negligible under these conditions. The removed incubation media were retained for the measurement of drug medium concentrations and subsequent determination of $\mathrm{K}_{\mathrm{p}}$ for each drug. The cells were lysed by addition of $200 \mu \mathrm{L}$ ice-cold deionised water; cell lysates were kept at $-20^{\circ} \mathrm{C}$ overnight and then processed further for LC-MS/MS analysis. Experiments were performed on three or more separate occasions for each drug investigated. Clarithromycin uptake at $5 \mu \mathrm{M}$ was used as a control to assess the performance of individual experiment. The mean uptake of the $5 \mu \mathrm{M}$ clarithromycin across a large number of experiments performed $(n=59)$ was $5.50 \pm 2.96 \mu \mathrm{l} / \mathrm{min} / 10^{6}$ cells. The amount of protein per well was measured using a BSA calibration curve and absorbances read at $562 \mathrm{~nm}$ (S22 Boeco UVVisible Spectrophotometer, Hamburg, Germany). Determination of cell number from measured protein was reproducible across experiments $\left(1 \times 10^{6}\right.$ cells $=0.25 \pm$ $0.06 \mathrm{mg}$ protein, $n=66$ ).

\section{Assessment of Lysosomal Sequestration in NR8383 Cells with LysoTracker Red}

Qualitative assessment of the localisation of lysosomes in NR8383 and lysosomal targeting of drugs investigated was made using LTR (Life Technologies, Paisley, UK). The protocol used for staining of the cells with LTR was adapted from a previous study (32). Clear flat bottom Ibidi 8-well chamber slides (Thistle Scientific, Glasgow, UK) were previously coated with $50 \mu \mathrm{g} / \mathrm{mL}$ collagen-I solution $(4.05 \mathrm{mg} / \mathrm{mL}$ Collagen type I rat tail, BD Biosciences, Oxford, UK). NR8383 cells
(250,000 cells/well) were plated in the slides and cultured for $16 \mathrm{~h}$ to $70-80 \%$ confluency and to ensure attachment. Stock solutions of $\mathrm{NH}_{4} \mathrm{Cl}$, monensin and nigericin were prepared by diluting them in serum-free Ham's F12K medium resulting in final incubation concentrations of $20 \mathrm{mM}, 5 \mu \mathrm{M}$ and $10 \mu \mathrm{M}$, respectively. In addition, stock solutions of clarithromycin, imipramine and formoterol were diluted in fresh serum-free Ham's F12K medium containing $1 \mathrm{mM}$ ABT to achieve final incubation concentrations of $5 \mu \mathrm{M}$. LysoTracker Red was added into the solutions of the chemical agents and the drugs to achieve a final concentration of $200 \mathrm{nM}$ as used previously (14). A control solution of LTR at the same concentration was also prepared by dilution of the original DMSO stock in serum-free Ham's F12K medium. Upon reaching confluency, cells were examined under the microscope (Olympus CK2, Olympus Optical Co., Japan), the CGM was removed and the cells were pre-treated with $300 \mu \mathrm{L}$ warm DPBS containing $1 \mathrm{mM} \mathrm{ABT}$ for $20 \mathrm{~min}$ at $37^{\circ} \mathrm{C}$ in the presence of $5 \% \mathrm{CO}_{2}$ $\left(\mathrm{CO}_{2}\right.$ incubator, MCO-17AIC, Sanyo Biomedical, Loughborough, UK). Following this, the cells were treated with $300 \mu \mathrm{L}$ of serum-free Ham's F12K medium containing either LTR alone (control) or LTR with each of the chemical agents or selected drugs for $1 \mathrm{~h}$ at $37^{\circ} \mathrm{C}$ in the $\mathrm{CO}_{2}$ incubator and protected from light. Following the incubation, the cells were washed three times with $300 \mu \mathrm{L}$ ice-cold DPBS and immediately fixed with $4 \%(v / v)$ formaldehyde in DPBS for $10 \mathrm{~min}$ at room temperature, protected from light. The cells were then treated with $50 \mathrm{mM} \mathrm{NH}_{4} \mathrm{Cl}$ in DPBS to quench the residual formaldehyde fluorescence for $5 \mathrm{~min}$ at room temperature. Three subsequent washes with ice-cold DPBS were performed before visualisation of LTR with a confocal laser scanning microscope (Zeiss LSM 510, Jena, Germany) using a C-Apochromat 40×/1.2 NA (Numerical Aperture) waterimmersion objective and helium/neon laser $\left(\lambda_{\text {excitation }}\right.$ $543 \mathrm{~nm}, \lambda_{\text {emmision }} 560 \mathrm{~nm}$ ). Images were collected and processed using Combi LSM-FCS v.3.2 and LSM Image Browser v4.2 software (Jena, Germany). Furthermore, Image J v1.47 software was used for the quantification of the fluorescence intensity of LTR in absence or presence of chemical agents and basic drugs (Image J, National Institutes for Health, US). The corrected total cell fluorescence (CTCF) was calculated as integrated density - (area of selected cell x mean fluorescence of background reading) (33). The CTCF of treated cells was compared to $100 \%$ control (LTR only).

\section{Lysosomal Sequestration Studies in NR8383}

The extent of accumulation of drugs in lysosomes was assessed using the same uptake methodology, as described above in the absence and presence of $\mathrm{NH}_{4} \mathrm{Cl}$ and ionophores, monensin and nigericin. Preliminary investigation of imipramine and clarithromycin uptake was performed across a range of $\mathrm{NH}_{4} \mathrm{Cl}$ concentrations $(10-50 \mathrm{mM})$, based on previous studies 
in the literature (12-14,34). In addition, a range of incubation conditions was explored, including pre-incubation and coincubation alone and combined together. Once the conditions were optimised, further experiments were performed with $20 \mathrm{mM} \mathrm{NH} 4 \mathrm{Cl}$ co-incubated with investigated drugs. The details of this optimisation work can be found in the Supplementary Material, Table S2 and Figure S3. Following the initial assessment with $\mathrm{NH}_{4} \mathrm{Cl}$, confirmation of lysosomal sequestration for a number of selected drugs was further carried out by co-incubation of $5 \mu \mathrm{M}$ monensin or $10 \mu \mathrm{M}$ nigericin with the selected drugs. The concentrations of both ionophores used in this study were optimised based on previous reports $(13,14,34)$ and in house solubility observations. Stock solutions of $\mathrm{NH}_{4} \mathrm{Cl}$, monensin and nigericin were in deionised water, methanol and chloroform respectively. For incubations with $\mathrm{NH}_{4} \mathrm{Cl}$, all drugs were prepared at 5 and $20 \mu \mathrm{M}$ concentrations, with the exception of ciprofloxacin due to solubility issues at higher concentrations. In the case of clarithromycin, its accumulation was further evaluated in the presence and absence of $\mathrm{NH}_{4} \mathrm{Cl}$ over a wide substrate concentration range. The incubation time points with $\mathrm{NH}_{4} \mathrm{Cl}$ were up to $10 \mathrm{~min}$ based on the previous data on the changes in lysosomal $\mathrm{pH}$ with this agent reported in mouse peritoneal macrophages (35). For incubations with monensin and nigericin, all drugs were prepared at $5 \mu \mathrm{M}$ concentration and the incubations were carried out for $5 \mathrm{~min}$ (single time point). Following the treatment of the cell monolayers with drug alone or drug with the agents mentioned, incubations were stopped by washing of the cells with ice-cold DPBS as described above, followed by cell lysis in deionised water. All incubations were carried out in duplicate and experiments were performed for three separate occasions. The removed incubation media were retained for the measurement of drug concentrations and subsequent determination of $\mathrm{K}_{\mathrm{p}}$ for each compound. Analysis of samples in LC-MS/MS was performed after cells were kept at $-20^{\circ} \mathrm{C}$ overnight.

\section{Cytotoxicity Assessment}

Lactate dehydrogenase (LDH) assay kit (Sigma-Aldrich, Dorset, UK) was used to measure the cytotoxicity of the chemical agents used to assess the extent of lysosomal sequestration relative to untreated cells. In addition, the cytotoxicity was assessed at high drug concentrations ( 50 and $100 \mu \mathrm{M}$ ) in cases where uptake was investigated over a substrate concentration range. The viability of the untreated cells and the effect of the individual drugs and chemical agents, as well as the effect of their combined use were assessed. Therefore, four types of samples were included in the analysis; namely, the incubation medium consisting of DPBS alone (negative control), drug alone (e.g., clarithromycin), chemical agents alone (e.g., $\mathrm{NH}_{4} \mathrm{Cl}$ ), and chemical agent and drug combination (e.g., $\mathrm{NH}_{4} \mathrm{Cl}+$ clarithromycin). For the assessment of the individual chemical agents, same concentrations were used as in the lysosomal sequestration studies. The cytotoxicity in above samples was measured on three separate occasions. The LDH activity of the experimental samples was compared against the $100 \%$ activity of the $\mathrm{LDH}$ positive control included in the assay kit. All samples and standards were run in duplicate and absorbance values were measured using a plate reader (Tecan Safire, A-5082, Reading, UK). Data acquisition was performed using Magellan software (version 7.1, Tecan Group Ltd., Austria).

\section{Sample Preparation and LC-MS/MS Analysis}

All cell lysates and media samples were thawed and quenched with methanol containing internal standard. The internal standard concentration was $1 \mu \mathrm{M}$ for all drugs except for budesonide and rifampicin for which $0.1 \mu \mathrm{M}$ was used. For cell lysate and media samples, equal volume of methanol/ internal standard mixture $(200 \mu \mathrm{L})$ was used. Media samples with substrate concentrations of $10 \mu \mathrm{M}$ and above were diluted down to $2 \mu \mathrm{M}$ with DPBS before quenching with the same volume of methanol/internal standard mixture $(200 \mu \mathrm{L})$. This initial dilution was performed to avoid saturation of ionisation in LC-MS/MS at high concentrations. Samples were placed at $-20^{\circ} \mathrm{C}$ for at least an hour to precipitate the proteins, followed by their centrifugation at $2500 \mathrm{rpm}$ for $10 \mathrm{~min}$ (Eppendorf Centrifuge 5804, Cambridge, UK). Ten or $20 \mu \mathrm{L}$ of supernatant was analysed by LC-MS/MS as detailed below.

Samples were analysed on a Waters Alliance 2795 HPLC system coupled to a Micromass Quattro Ultima mass spectrometer (Waters, Watford, UK) using electrospray positive ionisation mode. All compounds and their internal standards were separated on Luna C18 column $(3 \mu \mathrm{m}, 50 \times 4.6 \mathrm{~mm})$ (Phenomenex, Macclesfield, UK), except for fenoterol, terbutaline, ipratropium and tiotropium bromide which were separated on Luna Phenyl Hexyl column $(3 \mu \mathrm{m}, 50 \times 4.6 \mathrm{~mm})$ (Phenomenex, Macclesflield, UK). The mobile phases used were: Solvent A, 90\% water, 10\% methanol, and $0.05 \%$ formic acid; Solvent B, 10\% water, 90\% methanol, and 0.05\% formic acid; Solvent C, 90\% water, 10\% methanol, and $1 \mathrm{mM}$ ammonium acetate; and Solvent D, 10\% water, $90 \%$ methanol, and $1 \mathrm{mM}$ ammonium acetate. The gradient of mobile phases varied for each drug. The flow rate through HPLC was $1 \mathrm{~mL} / \mathrm{min}$, which was then split to $0.25 \mathrm{~mL} / \mathrm{min}$ before entry into the mass spectrometer. For the Waters Ultima, the capillary voltage was $3.5 \mathrm{kV}$; desolvation and source temperatures were 350 and $125^{\circ} \mathrm{C}$, respectively; desolvation gas and cone gas flow rates were 600 and 150 L/h, respectively. LC-MS/MS conditions for each individual drug and their corresponding internal standards are detailed in Supplementary Material, Table S3. A calibration standard, containing the compound of investigation at a 
concentration range covering that of the experimental samples with an additional zero blank, was prepared in the same matrix of the experimental samples and analysed twice (before and after the experimental samples) during each run, in order to confirm compound stability, consistent peak area for internal standard and any potential compound carry over. Samples were quantified against the standard curve using MassLynx v.4.1 (Waters Inc., Milford, MA). During analysis, only standards which were measured within $30 \%$ of the nominal concentration were included in the standard curve.

\section{Determination of Uptake Clearance Parameters}

The $\mathrm{CL}_{\text {uptake }}$ and $\mathrm{CL}_{\text {diff }}$ were estimated at a single substrate concentration for each drug from the 37 and $4^{\circ} \mathrm{C}$ data, respectively. Uptake rate was determined from the slope of the linear regression of the cell concentration vs. time plot. Total uptake clearance was then estimated from the ratio of the uptake rate against the substrate concentration. Both $\mathrm{CL}_{\text {uptake }}$ and $\mathrm{CL}_{\text {diff }}$ were determined for each drug on a minimum three separate occasions. Uptake clearance attributed to the active process(es) was determined from the difference between $\mathrm{CL}_{\text {uptake }}$ and $\mathrm{CL}_{\text {diff }}$ for each drug (36).

\section{Determination of Drug Accumulation}

Accumulation of drugs in NR8383 was determined by calculating $\mathrm{K}_{\mathrm{p}}$ of all drugs at $5 \mu \mathrm{M}$ at $10 \mathrm{~min}$. $\mathrm{K}_{\mathrm{p}}$ was determined by Eq. 1 as reported previously $(36,37)$;

$\mathrm{K}_{\mathrm{p}}=\frac{\mathrm{C}_{\text {cell }}}{\mathrm{C}_{\text {medium }}}$

where $\mathrm{C}_{\text {cell }}$ and $\mathrm{C}_{\text {medium }}$ represent concentration of the drug in the cell and medium, respectively. Both represent the measurements made at the final incubation time point (10 min). The $\mathrm{K}_{\mathrm{p}}$ represents partition of the drug into total cell and reflects intracellular binding, subcellular distribution and active and passive uptake processes. $\mathrm{C}_{\text {cell }}$ was calculated by multiplying the measured lysate concentration with lysate volume $(200 \mu \mathrm{L})$ and dividing this amount by the cell volume $\left(1.04 \mu \mathrm{L} / 10^{6}\right.$ cells, $\left.\mathrm{CV}=24 \%\right)$ and number of cells measured per well. Cell volume was calculated by multiplying the reported NR8383 volume of $4.2 \mu \mathrm{L} / \mathrm{mg}$ protein (38) with the amount of protein measured experimentally $(0.25 \pm 0.06 \mathrm{mg} /$ $10^{6}$ cells). While $\mathrm{K}_{\mathrm{p}}$ was determined at a single substrate concentration for all the drugs investigated, the accumulation of 3 basic drugs including imipramine, clarithromycin and formoterol was also characterised over a concentration range at the same incubation time. The concentration dependence of drug accumulation was investigated by fitting the two-site binding model to the $\mathrm{K}_{\mathrm{p}}$ and concentration data in GraFit v6.0.6 software (Erithacus Software Limited, Horley, UK).
The model incorporates a saturable site and a linear function for unsaturated binding as shown in Eq. 2;

$\mathrm{K}_{\mathrm{p}}=\mathrm{K}_{\mathrm{p}, \mathrm{U} \mathrm{l}, \max }-\frac{\mathrm{K}_{\mathrm{p}, \mathrm{U} \mathrm{l}, \text { max }} \cdot \mathrm{C}_{\text {medium }}}{\mathrm{K}_{\mathrm{U} \mathrm{I}}+\mathrm{C}_{\text {medium }}}+\mathrm{K}_{\mathrm{p} \text {,min }}$

where $\mathrm{K}_{\mathrm{p}, \mathrm{U} 1 \text {,max }}$ is maximum $\mathrm{K}_{\mathrm{p}}$ for saturable uptake, $\mathrm{K}_{\mathrm{p} \text {,min }}$ is $\mathrm{K}_{\mathrm{p}}$ for nonsaturable uptake and $\mathrm{K}_{\mathrm{U} 1}$ is apparent saturable uptake equilibrium constant. $\mathrm{K}_{\mathrm{p}}$ for maximum total uptake was calculated as the sum of $\mathrm{K}_{\mathrm{p}, \mathrm{U} 1, \max }$ and $\mathrm{K}_{\mathrm{p}, \min }$, as reported previously (39).

\section{Determination of Uptake Kinetic Parameters of Clarithromycin}

The estimation of uptake kinetic parameters of clarithromycin was performed using the two-step method $(31,36)$ for analysis in GraFit v6.0.6 (Erithacus Software Limited, Horley, UK). $\mathrm{CL}_{\text {diff }}$ was estimated from the slope of the linear regression of the substrate concentration vs. uptake rates estimated at $4^{\circ} \mathrm{C}$ and used as a constant parameter in Eq. 3. When estimating the uptake kinetic parameters in the presence of $\mathrm{NH}_{4} \mathrm{Cl}$, $\mathrm{CL}_{\text {diff }}$ estimated at single substrate concentration was used a constant in the equation. Subsequently, kinetic parameters $\mathrm{K}_{\mathrm{m}}{ }^{\prime}$ and $\mathrm{V}_{\max }$ were obtained by nonlinear regression.

$\mathrm{v}=\frac{\mathrm{V}_{\text {max }} \times \mathrm{S}_{\mathrm{med}}}{\mathrm{K}_{\mathrm{m}}^{\prime}+\mathrm{S}_{\mathrm{med}}}+\mathrm{CL}_{\mathrm{diff}} \times \mathrm{S}_{\mathrm{med}}$

where $\mathrm{v}$ is the uptake rate, $\mathrm{K}_{\mathrm{m}}{ }^{\prime}$ is the binding affinity constant and $\mathrm{V}_{\max }$ is the maximum uptake rate associated with an active process mediating uptake of clarothromycin into AM. $\mathrm{S}_{\text {med }}(\mu \mathrm{M})$ is the nominal media concentration corrected for fraction unbound in the media $\left(\mathrm{fu}_{\mathrm{med}}=0.93 \pm 0.03\right)$. The latter was determined from the slope of the linear regression of the unbound concentration extrapolated at time $0 v s$. the nominal incubation concentration plot.

\section{Determination of Lysosomal Sequestration}

$\mathrm{K}_{\mathrm{p}}$ and $\mathrm{CL}_{\text {uptake }}$ were determined as described above for each drug both under control condition and in the presence of a chemical agent affecting the $\mathrm{pH}$ gradient between cytosol and lysosomes. The reduction in $\mathrm{K}_{\mathrm{p}}$ and $\mathrm{CL}_{\text {uptake }}$ of each drug in the presence of the chemical agents was expressed as a percentage relative to control and used as an indicator of the extent of lysosomal sequestration. A 50\% reduction in both parameters was set as a cut-off for lysosomal accumulation, while also taking into account the physicochemical properties of the compounds (Table I) and the uncertainty associated with the experimental data.

The in vitro parameters were calculated on at least three separate occasions and the mean data were reported. When assessing the extent of lysosomal sequestration, the control and 
chemical agent treated cells were compared using the twotailed, paired $t$-test in order to determine statistically significant difference between the two conditions. Values were reported as significant when $p<0.05$.

\section{RESULTS}

\section{Drug Accumulation in NR8383 Cell Line}

Accumulation of 10 drugs was assessed in NR8383 at a single substrate concentration $(5 \mu \mathrm{M})$ at $37^{\circ} \mathrm{C}$. Measured cell and media concentrations of all drugs were used to determine their $\mathrm{K}_{\mathrm{p}}$, as shown in Table II. More than 500-fold range in $\mathrm{K}_{\mathrm{p}}$ was observed in NR8383 for the current dataset. The most extensive accumulation in NR8383 was seen for imipramine and clarithromycin ( $K_{\mathrm{p}}$ of 391 and 82, respectively). Ciprofloxacin, rifampicin, budesonide and formoterol accumulated in NR8383 to a similar extent $\left(\mathrm{K}_{\mathrm{p}}\right.$ values ranging between 25 and 43). For the remaining drugs, relatively less partitioning into cells was observed, as tiotropium, ipratropium bromide and fenoterol achieved a $\mathrm{K}_{\mathrm{p}}$ between 5 and 9. In the case of terbutaline, the medium concentration of the compound remained higher than its cell concentration throughout the incubation period, resulting in $\mathrm{K}_{\mathrm{p}}$ close to 1 .

For a number of basic drugs, accumulation in the NR8383 was assessed further over a range of substrate concentrations. A concentration-dependent accumulation was observed for the drugs investigated, as illustrated in Fig. 1. The two-site binding model was fitted to the experimental data and the estimated uptake parameters $\mathrm{K}_{\mathrm{p}, \mathrm{U} 1 \text {,max }}, \mathrm{K}_{\mathrm{p} \text {,min }}$ and $\mathrm{K}_{\mathrm{U} 1}$ are shown in Table III. In contrast to the $\mathrm{K}_{\mathrm{p}}$ value obtained at $5 \mu \mathrm{M}$, imipramine maximum $\mathrm{K}_{\mathrm{p}}$ of 1166 was estimated by the modelling approach (corresponds to concentration $<0.1 \mu \mathrm{M}$ ). The $\mathrm{K}_{\mathrm{p} \text {,min }}$ of 141,24 and 10 was estimated for imipramine, clarithromycin and formoterol, respectively. The analysis indicated that half of maximal $\mathrm{K}_{\mathrm{p}}$ associated with saturable uptake would be reached at concentrations below $2 \mu \mathrm{M}$ for these three drugs (Table III). The fold difference between $\mathrm{K}_{\mathrm{p}}$, max and $\mathrm{K}_{\mathrm{p} \text {,min }}$ ranged between 3 and 8 for clarithromycin and imipramine, respectively.

Uptake of 10 drugs was also assessed in NR8383 at $5 \mu \mathrm{M}$ at 37 and $4^{\circ} \mathrm{C}$ in order to delineate contribution of active and passive diffusion processes to the overall uptake into AMs (Table II). The trends seen in the intracellular accumulation data were reflected in the uptake clearances, with over 400fold range in $\mathrm{CL}_{\text {uptake }}$ in NR8383 observed for the current dataset $\left(0.04-16.7 \mu \mathrm{L} / \mathrm{min} / 10^{6}\right.$ cells). Imipramine showed the highest uptake clearance in NR8383 $\left(16.7 \mu \mathrm{L} / \mathrm{min} / 10^{6}\right.$ cells) with maximal contribution of the passive process to the total uptake of approximately 30\%. Negligible $\mathrm{CL}_{\text {diff }}$ was observed for clarithromycin, suggesting a large contribution of an active process to its accumulation in NR8383. The same trend was observed for the majority of drugs with the exception of terbutaline and budesonide where contribution of passive diffusion to accumulation in NR8383 was $>50 \%$ (Table II). Fenoterol, terbutaline, ipratropium and tiotropium bromide were marginally taken up into NR8383 cells with a $\mathrm{CL}_{\text {uptake }}$ of $<1 \mu \mathrm{L} / \mathrm{min} / 10^{6}$ cells.

\section{Confocal Microscopic Examination of NR8383 Cells and Lysosomal Sequestration}

The imaging of NR8383 cells was performed in order to confirm localisation of functional lysosomes in NR8383 and assess the effect of the chemical agents on LTR accumulation in these organelles. In addition, the lysosomal targeting of selected drugs was investigated. A differential contrast image was taken every time prior to excitation of the cells for LTR detection. A representative of this image is shown in Fig. 2a, demonstrating the presence of cytoplasmic vesicular structures likely to represent acidic organelles including lysosomes. The

Table II Drug Uptake Clearance and Cell-to-Medium Concentration Ratio $\left(K_{\mathrm{p}}\right)$ of I 0 Drugs in NR8383 at $5 \mu$ M Substrate Concentration. Data Represent

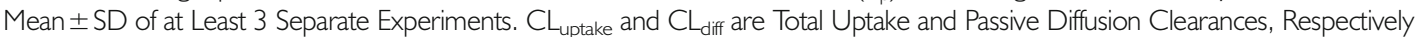

\begin{tabular}{|c|c|c|c|c|}
\hline Drug & $\begin{array}{l}\mathrm{CL}_{\text {uptake }} \\
\left(\mu \mathrm{L} / \mathrm{min} / 10^{6} \text { cells }\right)\end{array}$ & $\begin{array}{l}\mathrm{CL}_{\text {diff }} \\
\left(\mu \mathrm{L} / \mathrm{min} / 10^{6} \text { cells }\right)\end{array}$ & $\begin{array}{l}\text { Contribution } \\
\text { of passive (\%) }\end{array}$ & $K_{p}$ \\
\hline Imipramine & $16.7 \pm 4.3$ & $5.06 \pm 1.7$ & 30.2 & $391 \pm 108$ \\
\hline Clarithromycin & $6.0 \pm 3.7$ & $0.03 \pm 0.03$ & 0.53 & $81.6 \pm 22.8$ \\
\hline Formoterol & $2.0 \pm 0.7$ & $0.08 \pm 0.08$ & 3.71 & $24.5 \pm 8.71$ \\
\hline Budesonide & $1.5 \pm 0.7$ & $1.5 \pm 0.9$ & 97.2 & $37.6 \pm 11.4$ \\
\hline Rifampicin & $1.4 \pm 0.5$ & $0.03 \pm 0.01$ & 1.87 & $38.6 \pm 18.1$ \\
\hline Ciprofloxacin & $1.3 \pm 0.4$ & $0.3 \pm 0.2$ & 22.3 & $43.0 \pm 21.1$ \\
\hline Tiotropium bromide & $0.4 \pm 0.3$ & $0.06 \pm 0.04$ & 16.3 & $8.74 \pm 7.24$ \\
\hline Fenoterol & $0.3 \pm 0.2$ & $0.03 \pm 0.01$ & 8.03 & $5.69 \pm 0.98$ \\
\hline Ipratropium bromide & $0.2 \pm 0.2$ & $0.01 \pm 0.01$ & 5.19 & $5.42 \pm 3.38$ \\
\hline Terbutaline & $0.04 \pm 0.01$ & $0.02 \pm 0.01$ & 47.6 & $0.69 \pm 0.16$ \\
\hline
\end{tabular}



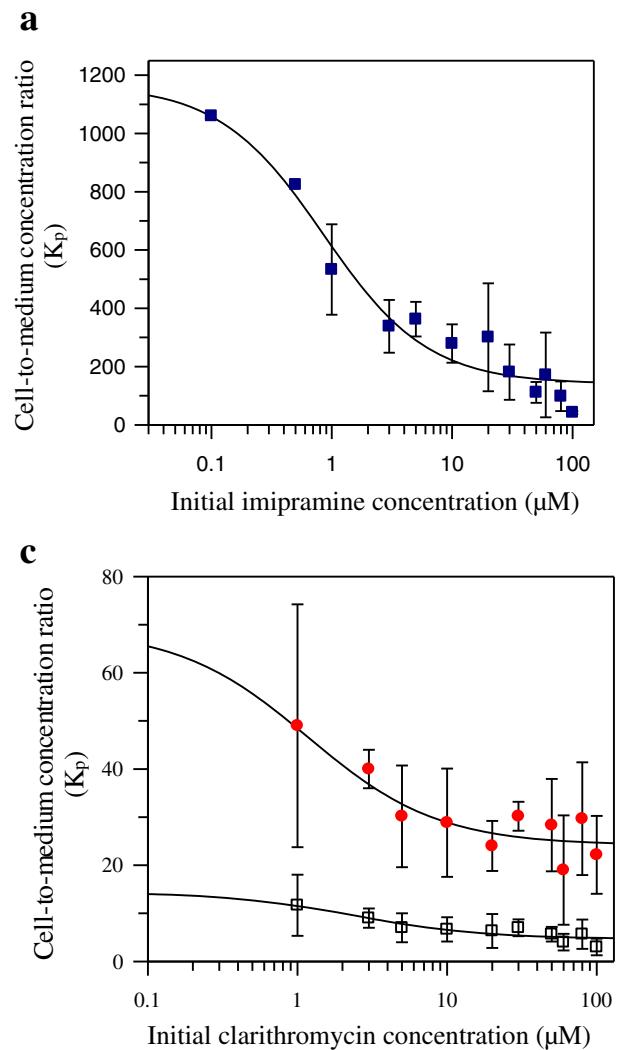

$\mathbf{b}$

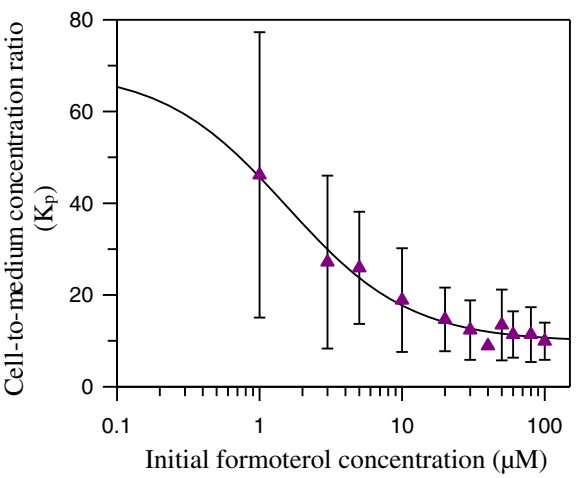

d

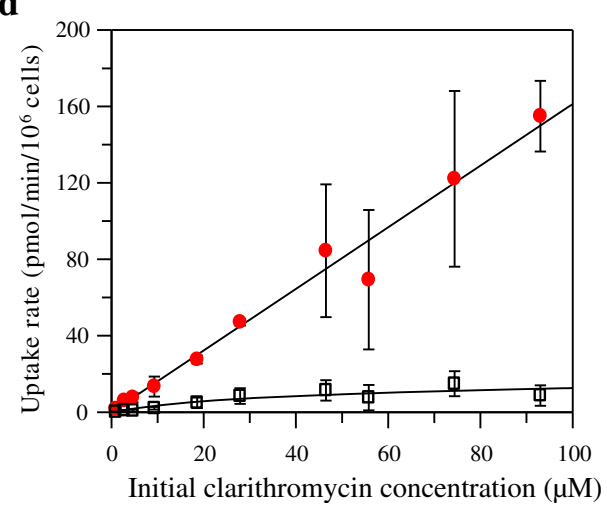

Fig. I Cell-to-medium concentration ratio $\left(K_{p}\right)$ of imipramine $(\mathbf{a})$, formoterol $(\mathbf{b})$ and clarithromycin $(\mathbf{c})$, and total uptake rate of clarithromycin (d) over a range of concentrations in NR8383 cells. Data represent mean \pm SD of 3 experiments except for the first two data points $(0.1-0.5 \mu$ M) of imipramine $(n=1)$. Solid line represents the fit for total uptake at $37^{\circ} \mathrm{C}$. Symbols represent the observed data in the absence ( $\boldsymbol{\square}$ imipramine; $\boldsymbol{\Delta}$ formoterol; $\bullet$ clarithromycin) and presence ( $\square$ ) of $20 \mathrm{mM} \mathrm{NH}_{4} \mathrm{Cl}$ at $37^{\circ} \mathrm{C}$. For $\mathrm{K}_{\mathrm{p}}$ and uptake kinetic parameter estimation, the fitting was obtained using the two-site binding model (Eq. 2) and the conventional two-step model (Eq. 3).

corresponding fluorescent image of the same cell is illustrated in Fig. 2b where LTR was localised in lysosomes, confirming the presence of these organelles in NR8383 cells. Treatment of NR8383 with LTR in the presence of $\mathrm{NH}_{4} \mathrm{Cl}(20 \mathrm{mM})$, monensin $(5 \mu \mathrm{M})$ and nigericin $(10 \mu \mathrm{M})$ showed reduced fluorescent signal up to $85 \%$ for all agents. The reduced accumulation of LTR in the presence of these agents (Fig. 2c, e, g) confirmed lysosomal targeting of this basic probe in NR8383. Assuming the competition of basic drugs for lysosomal sequestration, LTR was co-incubated with $5 \mu \mathrm{M}$ of clarithromycin, imipramine and formoterol. Clarithromycin and imipramine decreased LTR accumulation by 86 and $72 \%$, respectively (Fig. 2d, f), confirming indirectly the lysosomotropic properties of these two drugs. In contrast, the localisation of LTR was still evident in the presence of formoterol (Fig. 2h) which caused only 25\% reduction in LTR accumulation, suggesting its marginal targeting of NR8383 lysosomes.

\section{Cytotoxicity Assessment}

Analysis of all three agents either on their own or when coincubated with clarithromycin or imipramine showed minimal cytotoxicity (less than 2\% compared to $100 \%$ positive control). At all times, the viability of the control (i.e., untreated) cells was more than $95 \%$. The measured cytotoxicity was less than $1 \%$ for imipramine at both 50 and $100 \mu \mathrm{M}$

Table III Uptake Parameter Values for 3 Drugs Investigated in NR8383 Over a Concentration Range. $\mathrm{K}_{\mathrm{p}, \mathrm{U} \text {, max }}$, $\mathrm{K}_{\mathrm{p}, \text { min }}$ and $\mathrm{K}_{\mathrm{UI}}$ were Estimated Using the Two-Site Binding Model. Data Represent Mean \pm SD of 3 Experiments

\begin{tabular}{llllll}
\hline Drug & $K_{p, U I, \text { max }}$ & $K_{p, \text { min }}$ & $K_{U I}(\mu M)$ & $K_{p, \text { max }}$ & $K_{p, \text { max }} / K_{p, \text { min }}$ \\
\hline Imipramine & $1025 \pm 99.6$ & $141 \pm 30.6$ & $0.9 \pm 0.3$ & 1166 & 8.3 \\
Clarithromycin & $44.9 \pm 16.6$ & $24.2 \pm 2.06$ & $1.18 \pm 1.45$ & 69 & 2.9 \\
Formoterol & $59.2 \pm 8.77$ & $10.0 \pm 0.92$ & $1.54 \pm 0.49$ & 69 & 6.9 \\
\hline
\end{tabular}




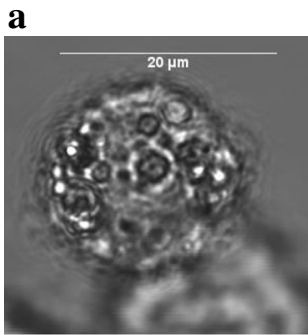

NR8383

b

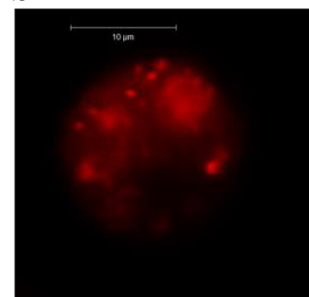

+LysoTracker Red

(Control)

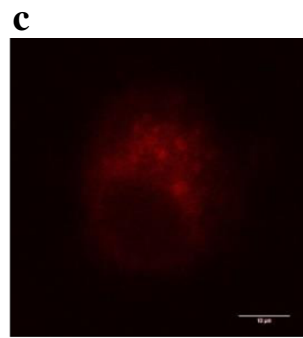

$+\mathrm{NH}_{4} \mathrm{Cl}$

d

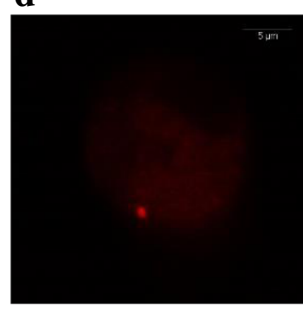

+ Clarithromycin

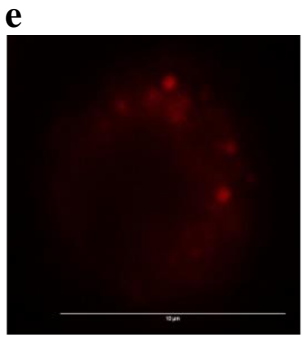

+ Monensin f

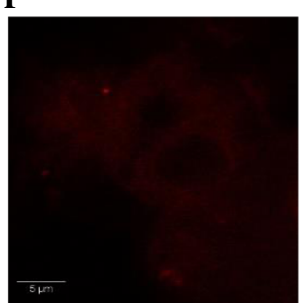

+ Imipramine

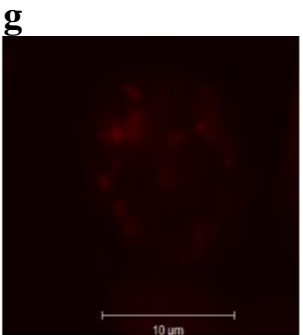

+ Nigericin

h

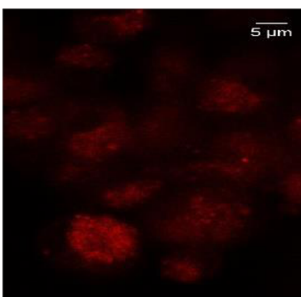

+ Formoterol

Fig. 2 Qualitative assessment of lysosomal sequestration of LysoTracker Red (LTR) and three drugs studied in NR8383 by confocal microscopy: (a) differential interference contrast image of a single NR8383 cell treated with 200 nM LTR; (b) the same cell being excited to detect LTR localised in lysosomes under control conditions; the localisation of LTR in the lysosomes of NR8383 was reduced in presence of $20 \mathrm{mM} \mathrm{NH} 4 \mathrm{Cl}(\mathbf{c}), 5 \mu \mathrm{M}$ monensin (d), $10 \mu \mathrm{M}$ nigericin (e), $5 \mu \mathrm{M}$ clarithromycin (f) and $5 \mu \mathrm{M}$ imipramine (g), and showed minor changes in presence of $5 \mu \mathrm{M}$ formoterol (h).

concentrations. For formoterol, the cytotoxicity was less than $5 \%$ compared to the positive control, whereas in the case of clarithromycin, the cytotoxicity levels were $<3 \%$ and $10 \%$ for $50 \mu \mathrm{M}$ and $100 \mu \mathrm{M}$ concentrations, respectively.

\section{Assessment of Lysosomal Sequestration in NR8383}

Lysosomal sequestration of 10 drugs was assessed in NR8383 cells using three different chemical agents. The analysis was performed initially with $20 \mathrm{mM} \mathrm{NH}_{4} \mathrm{Cl}$ co-incubated with each drug at $37^{\circ} \mathrm{C}$ for $10 \mathrm{~min}$. The $\mathrm{pH}$ of the incubation medium showed a minimal reduction in the presence of $\mathrm{NH}_{4} \mathrm{Cl}(<0.06$ unit) relative to control conditions. The effect of $\mathrm{NH}_{4} \mathrm{Cl}$ on the intracellular accumulation of individual drugs is shown in Fig. 3. Of all the drugs investigated, the most pronounced reduction in intracellular accumulation was observed for clarithromycin, as $\mathrm{K}_{\mathrm{p}}$ obtained at $5 \mu \mathrm{M}$ decreased by 6 -fold in the presence of $\mathrm{NH}_{4} \mathrm{Cl}$ relative to control condition, whereas in the case of imipramine 3.4-fold lower $\mathrm{K}_{\mathrm{p}}$ was seen (Table IV). The presence of $\mathrm{NH}_{4} \mathrm{Cl}$ in the incubation did not significantly alter the intracellular accumulation of the remaining drugs (Table IV and Supplementary Material, Table S4). Even though $\mathrm{K}_{\mathrm{p}}$ was reduced for some of the drugs (e.g., by $46 \%$ for ipratropium bromide), the large uncertainty associated with the data (both control and $+\mathrm{NH}_{4} \mathrm{Cl}$ data) resulted in no significant difference between the two conditions. For the majority of drugs, the $\%$ reduction in $\mathrm{K}_{\mathrm{p}}$ in the presence of $\mathrm{NH}_{4} \mathrm{Cl}$ was within $20 \%$ at both substrate concentrations.
Lysosomal sequestration of imipramine, clarithromycin, formoterol and fenoterol was investigated further by monensin and nigericin; total $\mathrm{K}_{\mathrm{p}}$ of these drugs in the absence and presence of these agents are shown in Fig. 4. The $\mathrm{K}_{\mathrm{p}}$ of imipramine was significantly reduced in the presence of both monensin (by $66 \%$ ) and nigericin (by 75\%). The reduction of clarithromycin $\mathrm{K}_{\mathrm{p}}$ was more pronounced in comparison to imipramine (77 and $82 \%$ by monensin and nigericin, respectively), in agreement with the effect of $\mathrm{NH}_{4} \mathrm{Cl}$. In contrast, minor reduction in fenoterol and formoterol $\mathrm{K}_{\mathrm{p}}$ in the presence of these agents was observed, corroborating findings from the studies with $\mathrm{NH}_{4} \mathrm{Cl}$. The observations from confocal imaging studies confirmed the results outlined above, with regards to both the effectiveness of the chemical agents and the extent of lysosomal accumulation of clarithromycin, imipramine and formoterol (Fig. 2). In addition to $\mathrm{K}_{\mathrm{p}}, \mathrm{CL}_{\text {uptake }}$ of each drug was estimated in the presence of these chemical agents; the effect of $\mathrm{NH}_{4} \mathrm{Cl}$, monensin and nigericin on $\mathrm{CL}_{\text {uptake }}$ of the drugs investigated followed the same trends seen for $\mathrm{K}_{\mathrm{p}}$ data (details are shown in the Supplementary Material, Table S5, Figures S4 and S5).

Among all drugs, the accumulation of clarithromycin in NR8383 in the presence of $\mathrm{NH}_{4} \mathrm{Cl}$ was further characterised over a range of clarithromycin concentrations $(1-100 \mu \mathrm{M})$. Compared to control conditions, a marked reduction in clarithromycin $\mathrm{K}_{\mathrm{p}}$ was observed at all drug concentrations (Fig. 1c). Estimated $\mathrm{K}_{\mathrm{p}, \mathrm{U} 1 \text {, max }}$ and $\mathrm{K}_{\mathrm{p} \text {,min }}$ values in the presence of $\mathrm{NH}_{4} \mathrm{Cl}$ were 9.7 and 4.7 , respectively, resulting in a mean maximum fitted $\mathrm{K}_{\mathrm{p}}$ of 14.4. Assessment of uptake kinetics of clarithromycin under the control conditions showed 
a

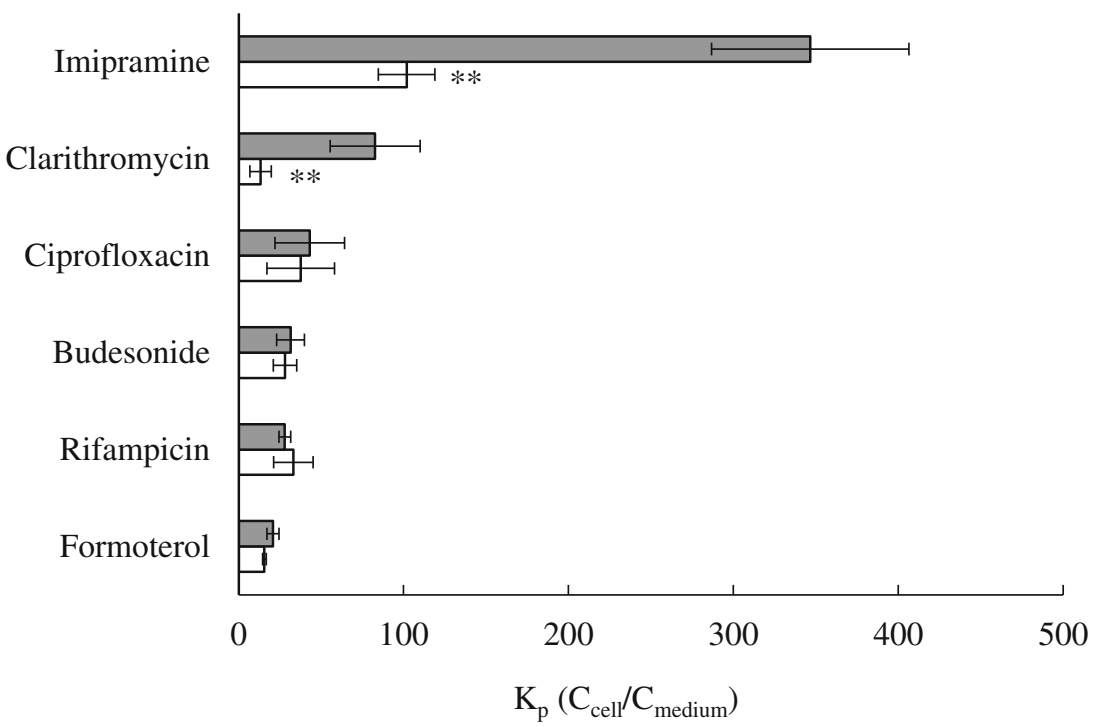

b

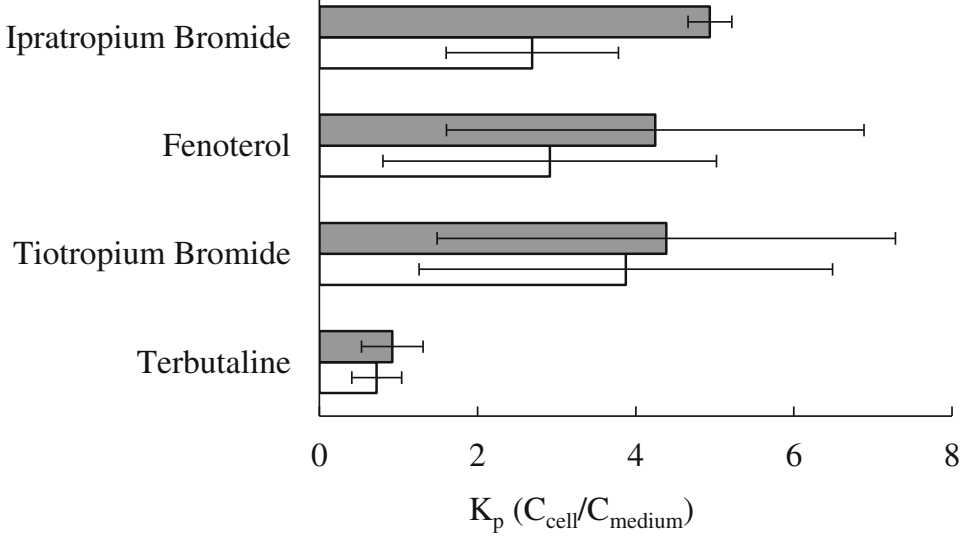

Fig. $3 \mathrm{~K}_{\mathrm{p}}\left(\mathrm{C}_{\text {cell }} / \mathrm{C}_{\text {medium }}\right)$ estimated in absence $(\square)$ (control) and presence $(\square)$ of $20 \mathrm{mM}$ ammonium chloride $\left(\mathrm{NH}_{4} \mathrm{Cl}\right)$ at $5 \mu$ M concentration of $(\mathbf{a})$ imipramine, clarithromycin, formoterol, rifampicin, budesonide, ciprofloxacin, and (b) ipratropium bromide, fenoterol, tiotropium bromide and terbutaline. Data represent mean \pm SD of at least 3 experiments carried out at separate occasions (**, $p<0.0$ I by $t$-test).

Table IV Cell-to-Medium Partition Coefficients $\left(\mathrm{K}_{\mathrm{p}}\right)$ Estimated Under Control and $\mathrm{NH}_{4} \mathrm{Cl}$ Treatment Conditions for 10 Drugs Investigated at $5 \mu \mathrm{M}$ in NR8383. Percent Reduction in $\mathrm{K}_{\mathrm{p}}$ in the Presence of $\mathrm{NH}_{4} \mathrm{Cl}(20 \mathrm{mM})$, monensin $(5 \mu \mathrm{M})$ and nigericin $(10 \mu \mathrm{M})$ is shown as an indicator of the extent of lysosomal Sequestration. Data Represent Mean \pm SD of at Least 3 Experiments

\begin{tabular}{|c|c|c|c|c|c|}
\hline \multirow[b]{2}{*}{ Drug } & \multirow[b]{2}{*}{$\mathrm{K}_{\mathrm{p}}$ Control } & \multirow[b]{2}{*}{$\mathrm{K}_{\mathrm{p}}+\mathrm{NH}_{4} \mathrm{Cl}$} & \multirow[b]{2}{*}{$\mathrm{NH}_{4} \mathrm{Cl}$} & \multicolumn{2}{|c|}{ \% Reduction in $\mathrm{K}_{\mathrm{p}}$ by } \\
\hline & & & & Monensin & Nigericin \\
\hline Imipramine & $347 \pm 59.8$ & $102 \pm 17.1$ & $7 I \pm 2.6^{* * *}$ & $75 \pm 11^{* *}$ & $66 \pm 11^{* *}$ \\
\hline Clarithromycin & $82.7 \pm 27.3$ & $13.3 \pm 6.50$ & $84 \pm 6.6^{* *}$ & $77 \pm 8.5^{* *}$ & $82 \pm 9.6^{* * *}$ \\
\hline Formoterol & $20.8 \pm 3.6$ & $15.5 \pm 1.16$ & $24 \pm 9.0$ & $40 \pm 7.5$ & $27 \pm 5.1^{*}$ \\
\hline Fenoterol & $4.25 \pm 2.64$ & $2.91 \pm 2.11$ & $31 \pm 23$ & $27 \pm 25$ & $30 \pm 12$ \\
\hline Terbutaline & $0.92 \pm 0.39$ & $0.72 \pm 0.31$ & $21 \pm 5.0$ & $\mathrm{n} / \mathrm{a}$ & $\mathrm{n} / \mathrm{a}$ \\
\hline Rifampicin & $27.9 \pm 3.54$ & $33.2 \pm 11.9$ & NR & $\mathrm{n} / \mathrm{a}$ & $\mathrm{n} / \mathrm{a}$ \\
\hline Tiotropium bromide & $4.39 \pm 2.90$ & $3.87 \pm 2.61$ & $12 \pm 1.8$ & $\mathrm{n} / \mathrm{a}$ & $\mathrm{n} / \mathrm{a}$ \\
\hline Ipratropium bromide & $4.94 \pm 0.30$ & $2.69 \pm 1.09$ & $46 \pm 21$ & $\mathrm{n} / \mathrm{a}$ & $\mathrm{n} / \mathrm{a}$ \\
\hline Budesonide & $31.5 \pm 8.46$ & $28.1 \pm 7.12$ & $10 \pm 7.8$ & $\mathrm{n} / \mathrm{a}$ & $\mathrm{n} / \mathrm{a}$ \\
\hline Ciprofloxacin & $43.0 \pm 21.1$ & $37.6 \pm 20.5$ & $15 \pm 13$ & $\mathrm{n} / \mathrm{a}$ & $\mathrm{n} / \mathrm{a}$ \\
\hline
\end{tabular}

$\mathrm{n} / \mathrm{a}$ not available, NR no reduction in $\mathrm{K}_{\mathrm{p}}{ }^{*}, \mathrm{p}<0.05 ;{ }^{* *}, p<0.0$ l by t-test 

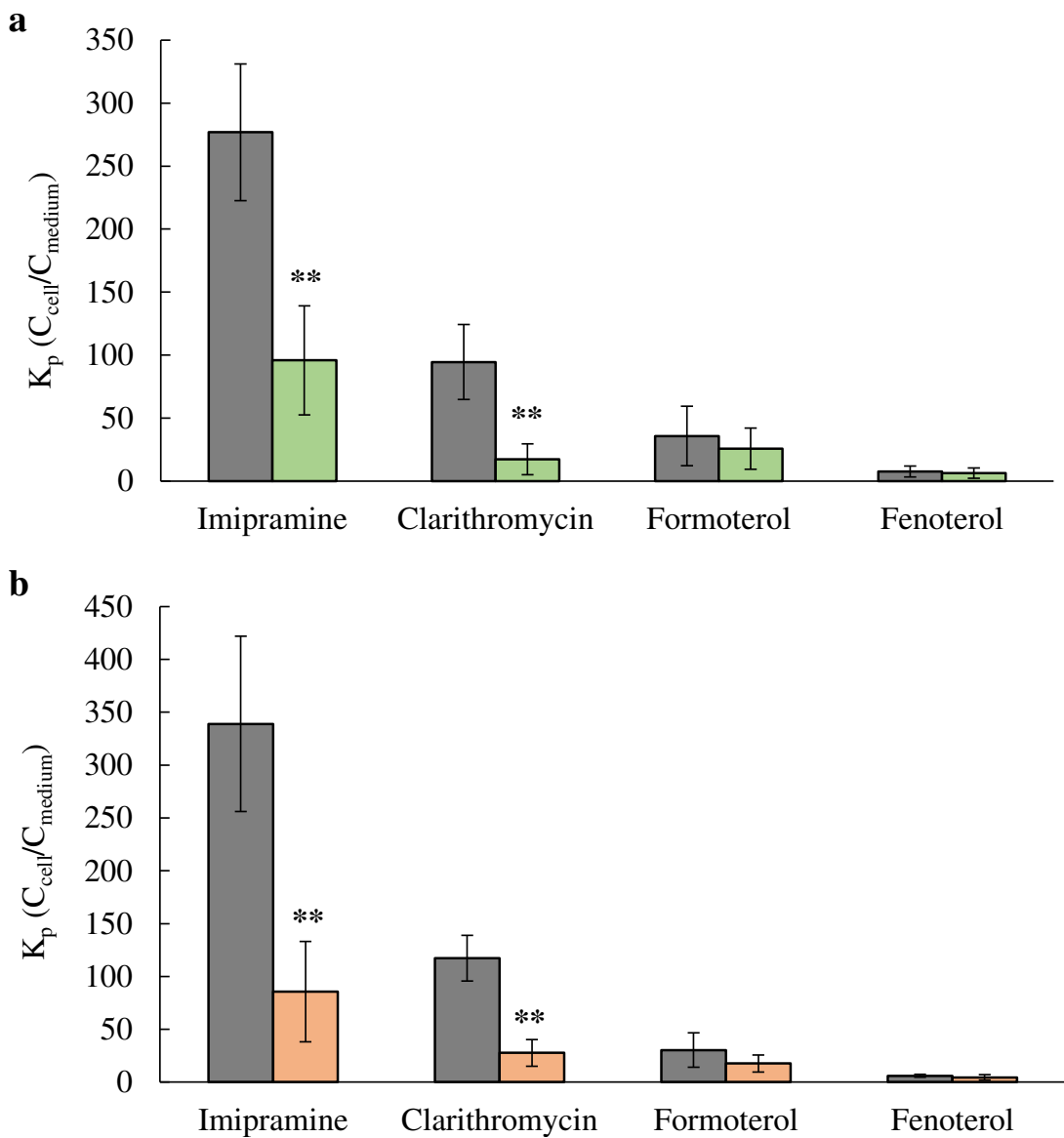

Fig. $4 \mathrm{~K}_{\mathrm{p}}\left(\mathrm{C}_{\text {cell }} / \mathrm{C}_{\text {medium }}\right)$ estimated in NR8383 in the absence $(\square)$ (control) and presence of $(\mathbf{a}) 10 \mu \mathrm{M}$ nigericin $(\square)(\mathbf{b}) 5 \mu \mathrm{M}$ monensin $(\square)$ at $5 \mu \mathrm{M}$ concentration of imipramine, clarithromycin, formoterol and fenoterol. Data represent mean \pm SD of at least 3 experiments $(* *, p<0.0$ l by $t$-test).

nonsaturating conditions up to $100 \mu \mathrm{M}$ and therefore, the kinetic parameters could not be determined. In contrast, in the presence of $\mathrm{NH}_{4} \mathrm{Cl}$, the uptake rates of clarithromycin were reduced markedly at all substrate concentrations compared to the control condition (Fig. 1d) and showed a saturable uptake kinetic profile (despite highly variable rates at higher concentrations, $\mathrm{CV}>30 \%$ ). In the presence of $\mathrm{NH}_{4} \mathrm{Cl}, \mathrm{K}_{\mathrm{m}}{ }^{\prime}$ and $\mathrm{V}_{\max }$ associated with the active uptake of clarithromycin into NR8383 were $28.5 \mu \mathrm{M}$ and $12.4 \mathrm{pmol} /$ $\mathrm{min} / 10^{6}$ cells, respectively; the corresponding clearance was $0.43 \mu \mathrm{L} / \mathrm{min} / 10^{6}$ cells. Considering estimated marginal contribution of the passive process, total clarithromycin $\mathrm{CL}_{\text {uptake }}$ $\left(0.46 \mu \mathrm{L} / \mathrm{min} / 10^{6}\right.$ cells $)$, was in agreement with the value obtained at a single concentration in the presence of $\mathrm{NH}_{4} \mathrm{Cl}$ (Supplementary Material, Figure S4).

\section{DISCUSSION}

Many clinically used drugs are basic and lipophilic, with a high propensity to accumulate in lysosome rich tissues, including the lungs. Depending on the location of intracellular drug targets the consequence of lysosomal sequestration varies, and could affect the efficacy of respiratory drugs targeting airway submucosal compartments (e.g., $\beta_{2}$-agonists and antimuscarinics). Drug accumulation in AMs may lead to formation of foamy macrophages (e.g., in drug induced phospholipidosis) and may raise safety concerns. Currently, there is a paucity of in vitro studies investigating the accumulation of respiratory drugs and potential lysosomal distribution in either primary human AMs or macrophage cell lines. In the current study, comprehensive analysis of uptake and lysosomal sequestration of 10 drugs was performed in NR8383. This rat alveolar macrophage cell line was selected as a representative AM system due to its ease of culturing and reported comparable characteristics to freshly isolated rat $\mathrm{AMs}(17,18)$.

\section{Assessment of Drug Accumulation and Membrane Partitioning in NR8383}

Following the optimisation of the methodology, the uptake of 10 drugs was investigated in NR8383 at a single concentration $(5 \mu \mathrm{M})$ limited by the analytical quantification of the cellular concentrations of the drugs investigated. The analysis showed pronounced differences in the extent of accumulation illustrated by over a 400 -fold range in both $\mathrm{CL}_{\text {uptake }}(0.04-17 \mu \mathrm{L} /$ 
$\min / 10^{6}$ cells) and $\mathrm{K}_{\mathrm{p}}(0.7-391)$ for the drugs in the dataset. Imipramine and clarithromycin, as the two most lipophilic basic drugs, showed the highest intracellular accumulation in NR8383, in agreement with previous studies reporting accumulation of clarithromycin and a number of CADs in AMs in vitro (12,40-42). A number of studies also reported substantial imipramine accumulation in isolated perfused lungs of rats (estimated $\mathrm{K}_{\mathrm{p}}$ of 17-44 depending on concentration), or other cell systems including rat hepatocytes $\left(\mathbf{K}_{\mathrm{p}, \max } 360\right)(37,43,44)$. Recently, clarithromycin $\mathrm{K}_{\mathrm{p}}$ of $\sim 16$ was reported in NR8383; the estimate is based on measurements at $10 \mathrm{~min}$ at $37^{\circ} \mathrm{C}$ and is approximately 5 -fold lower than the $\mathrm{K}_{\mathrm{p}}$ obtained here (12). This discrepancy can be explained by the use of much higher initial clarithromycin concentration $(50 \mu \mathrm{M})$ in the study by Togami et al. (2013) (12) compared to the current analysis. For the remaining respiratory drugs investigated, relatively lower intracellular accumulation in AMs was observed (Table II) reflective of their physicochemical properties. Most drugs have limited plasma membrane permeability due to being largely ionised and relatively hydrophilic at physiological $\mathrm{pH}$, and are non-amphiphilic in structure, supporting no extensive partitioning into membranes (Table I).

In this present study, the mechanisms driving the uptake of respiratory drugs in AMs were investigated at both 37 and $4^{\circ} \mathrm{C}$. Although the reliability of the $4^{\circ} \mathrm{C}$ approach to accurately determine passive diffusion is often questioned because of the reduced fluidity of the cellular membrane (45), this method was used as the presence of any membrane transporters in NR8383 is currently unknown, hence eliminating the possibility to assess the process by the use of specific transporter inhibitors. Uptake of most drugs into NR8383 was driven by an active process, reflected in $<25 \%$ contribution of the passive diffusion to the total uptake for 7/10 drugs investigated. The largest contribution of active uptake process(es) to overall intracellular accumulation in NR8383 was observed for clarithromycin. This finding is in agreement with Togami et al. study (12) that showed a reduction in clarithromycin $\mathrm{K}_{\mathrm{p}}$ by $90 \%$ in NR8383 at $4^{\circ} \mathrm{C}$ compared to its value at $37^{\circ} \mathrm{C}$. In the case of rifampicin, formoterol, ipratropium and tiotropium bromide, the supporting evidence for their active uptake comes from other systems such as HEK293 cells, Xenopus laevis oocytes and human airway epithelial cells in which the involvement of OATP, OCT and OCTN transporters was highlighted (46-51).

In addition to the analysis at a single drug concentration, the accumulation of imipramine, clarithromycin and formoterol (all basic drugs) in NR8383 was characterised further by determining $\mathrm{K}_{\mathrm{p}}$ over a range of substrate concentrations. The accumulation of these drugs was concentration-dependent and best described by a two-site model consisting of a saturable process, attributed to either transporter-mediated uptake and/or lysosomal sequestration, and a second linear process representing nonsaturable binding to membrane acidic phospholipids $(22,37,39)$. The two-site binding model allowed determination of the maximal extent of accumulation $\left(\mathrm{K}_{\mathrm{p}, \mathrm{max}}\right)$ of investigated drugs in AMs which can be difficult to assess analytically, as it requires use of very low substrate concentrations. The extent of saturable uptake was approximately 3-fold for clarithromycin, whereas the magnitude of this uptake was much greater for formoterol and imipramine $\left(\mathrm{K}_{\mathrm{p}, \max } / \mathrm{K}_{\mathrm{p}, \text { min }}\right.$ ratio of 6.9 and 8.3 , respectively). The accumulation profile of imipramine in NR8383 is in agreement with the study by Hallifax and Houston (37) who also described its accumulation in rat hepatocytes as a two-site process including a high affinity-low capacity component (saturable) and a low affinity-high capacity process (nonsaturable). Similar concept was also previously proposed for imipramine accumulation in lysosomes isolated from rat liver (52), where the high affinity-low capacity site was attributed to lysosomes considering the effect of $\mathrm{NH}_{4} \mathrm{Gl}$ seen. Based on these, the $\mathrm{K}_{\mathrm{p} \text {,min }}$ of the drugs at the highest substrate concentration can be assumed to represent membrane partitioning upon saturation of active processes. Imipramine, as a CAD well known to interact with membrane acidic phospholipids $(53,54)$, showed the highest membrane partitioning $\left(\mathrm{K}_{\mathrm{p}, \min }\right.$ of 141$)$ whereas in the case of clarithromycin and formoterol $\mathrm{K}_{\mathrm{p} \text {,min }}$ values were 5 to 14 -fold lower (Table III). This less pronounced partitioning into membranes (lysosomal and cellular plasma membrane) is not surprising considering the non-amphiphilic and relatively less lipophilic nature of clarithromycin and formoterol relative to imipramine.

\section{Assessment of Lysosomal Sequestration of Drugs in NR8383}

Lysosomal sequestration is an important active process that may contribute to intracellular drug accumulation. The qualitative assessment of this process was performed with LTR staining of NR8383 in the absence and presence of $\mathrm{NH}_{4} \mathrm{Cl}$, monensin and nigericin, agents known to abolish lysosome-cytosol $\mathrm{pH}$ gradient. In the quantitative analysis, the reduction in total drug uptake clearance and accumulation by the mentioned chemical agents was assessed. This indirect method provides an advantage over methods requiring cell homogenisation and differential centrifugation to isolate lysosomes, as it is simple, rapid and allows a larger number of compounds to be assessed. In addition, it avoids issues of poor recovery, potential contamination of lysosomes and drug diffusion from these organelles during sample preparation. The extent of reduction in intracellular accumulation of investigated drugs in NR8383 obtained in the presence of chemical agents differed substantially for the drugs in the dataset. No or minimal reduction in $\mathrm{K}_{\mathrm{p}}(<15 \%)$ was observed for zwitterions rifampicin and ciprofloxacin, neutral budesonide and permanently cationic tiotropium bromide. Among basic drugs, the reduction in $\mathrm{K}_{\mathrm{p}}$ was in the range of $20-40 \%$ for formoterol, fenoterol and terbutaline. Out of all drugs, significant lysosomal accumulation in NR8383 was observed only for basic imipramine and clarithromycin (reduction in $\mathrm{K}_{\mathrm{p}}$ of $65 \%$ 
and above). In the case of imipramine, the results were in agreement with the use of this drug as a prototypical CAD for the assessment of lysosomal sequestration, as demonstrated in numerous different in vitro systems either in the presence of the chemical agents (Supplementary Material, Table S1) or LTR $(14,55)$. Although clarithromycin is cationic, it is not an amphiphilic drug due to the absence of the typical hydrophobic moiety (an aromatic and/or aliphatic ring structure) present in many CADs (56). However, macrolides have been indicated to be one of the few exceptions which lack the typical CAD structure yet cause phospholipidosis linked to lysosomal sequestration (5). Lysosomal accumulation of clarithromycin was observed for the first time across a concentration range, supported by the reduction in its $\mathrm{K}_{\mathrm{p}}$ in the presence of $\mathrm{NH}_{4} \mathrm{Cl}$ at all drug concentrations including $100 \mu \mathrm{M}$. These findings suggest that even at high concentrations, its intracellular accumulation was not driven solely by membrane partitioning but also by the lysosome-cytosol pH gradient. Therefore, the true membrane partitioning (i.e., $\mathrm{K}_{\mathrm{p}, \mathrm{min}}$ ) of clarithromycin is likely to be closer to the estimate obtained in the presence of $\mathrm{NH}_{4} \mathrm{Cl}$. No such data currently exist in the literature to allow direct comparison. Togami and colleagues previously showed that treatment of NR8383 with $\mathrm{NH}_{4} \mathrm{Cl}$ reduced the amount of clarithromycin in the cells by approximately half and the fraction of the drug in the granules compartment (containing the lysosomes) by $75 \%$ (12), in excellent agreement with the reduction in $\mathrm{K}_{\mathrm{p}}$ obtained in the current study.

The inclusion of basic drugs in this study was driven by their basic $\mathrm{pK}_{\mathrm{a}}$ (range from 8.14 to 9.9 ), which together with the lysosome-cytosol $\mathrm{pH}$ gradient suggested potential accumulation in the lysosomes (predicted $\mathrm{K}_{\mathrm{p} \text {,lysosome }}$ based on $\mathrm{pH}$ partitioning ranged between 315 and 443 for terbutaline and imipramine, respectively). However, under the experimental conditions used herein, 3 out of 5 basic drugs with $\log \mathrm{P}<3$ failed to show substantial lysosomal accumulation, suggesting that both sufficient lipophilicity and ionisation are required for lysosomal accumulation within relatively short incubation times. This finding was in agreement with a number of studies reporting lysosomal sequestration for drugs with $\log \mathrm{P}>2$ and $\mathrm{pK}_{\mathrm{a}}$ between 6.5 and $11(14,55)$. However, it is also evident that the mentioned physicochemical space is not definitive and that a number of drugs with these properties may fail to accumulate in the lysosomes. The discrepancy may be explained by the previous reports showing that drugs with similar octanol-water partition coefficients in unionised and ionised forms did not accumulate in the lysosomes to the same extent (mitochondrial accumulation was observed instead). This finding was in contrast to drugs for which partition coefficients of the ionised form were much lower relative to neutral (all have the above mentioned physicochemical properties) (15).

An important finding of the current lysosomal sequestration studies was the altered accumulation kinetics of clarithromycin in NR8383 when its lysosomal sequestration was significantly reduced in the presence of $\mathrm{NH}_{4} \mathrm{Cl}$. While it was not possible to determine the uptake kinetic parameters for clarithromycin under control incubation conditions, the initial uptake rates were substantially reduced in the presence of $\mathrm{NH}_{4} \mathrm{Cl}$ and the kinetic parameter estimates could be obtained. It is uncertain whether these estimates truly reflect the existence of a membrane transporter in NR8383 and further investigation of transporters expressed in this cell line is required. The existing evidence for clarithromycin being a substrate for membrane transporters is conflicting. Although it was previously shown that it was subject to active hepatic uptake (36), a more recent study demonstrated that clarithromycin was not a substrate for OATPs and OCT1 in vitro (transfected HEK293 cells) and in vivo in OATP and OAT gene knockout mice (57). One potential explanation for the more saturable kinetics under $\mathrm{NH}_{4} \mathrm{Cl}$ condition is the saturation of lysosomal accumulation with increasing clarithromycin concentration. These results further suggest that for CADs, macrolides and other basic lipophilic drugs which accumulate in the lysosomes, the uptake kinetic parameter estimates obtained may not represent the true transporter affinities and uptake rates without adequate consideration of the lysosomal sequestration. This is particularly important if in vitro generated uptake kinetic parameters are to be used in physiologically-based pharmacokinetic models to predict in vivo transporter-mediated disposition of these drugs (58-61). Considering many lysosomotropic drugs are cationic and amphiphilic, these results warrant the need for studies to investigate the impact of lysosomal sequestration on uptake kinetics of known OCT and OCTN substrates.

In conclusion, the current study is the first to provide a comprehensive analysis of the extent of accumulation of a range of respiratory drugs in alveolar macrophages and the mechanisms contributing to the observed intracellular drug concentrations. The current data suggest minimal sequestration of inhaled drugs in lysosomes of alveolar macrophages; however, formulation and particle size also need to be taken into consideration in the translation of the findings to the in vivo setting. The study has highlighted the importance of both lysosomal sequestration and binding to acidic phospholipids for extensive cellular accumulation in $\mathrm{AMs}$, which are distinct to transporter-mediated cellular uptake. Clarithromycin example clearly emphasizes the relevance of lysosomal sequestration on the understanding of the cellular accumulation kinetics and interplay with other active processes affecting intracellular drug concentrations. The abundance of lysosomes in NR8383, together with the data presented here, indicate potential application of this cell line in preclinical drug development as a routine system for investigation of lysosomal sequestration of new drug candidates. In addition, NR8383 may be used to predict the extent of respiratory drug accumulation in human AMs and to validate mechanistic in silico models 
developed to predict subcellular drug distribution. Therefore, this study provides a considerable scope for future research in the area of the prediction of respiratory drug accumulation in human alveolar macrophages.

\section{ACKNOWLEDGMENTS AND DISCLOSURES}

A.U. was supported by a $\mathrm{PhD}$ studentship from the Biotechnology and Biological Sciences Research Council, UK (BB/ 1532488/1) and GlaxoSmithKline, Stevenage, UK. The authors acknowledge Sue Murby and Dr David Hallifax (University of Manchester) for assistance with the analytical assays and useful discussions on data analysis, and Dr Alain Pluen (University of Manchester) for his assistance with confocal imaging. Part of this work was presented at the 10th International ISSX Meeting in Toronto, Canada, September 29 - October 3, 2013.

Open Access This article is distributed under the terms of the Creative Commons Attribution 4.0 International License (http://creativecommons.org/licenses/by/4.0/), which permits unrestricted use, distribution, and reproduction in any medium, provided you give appropriate credit to the original author(s) and the source, provide a link to the Creative Commons license, and indicate if changes were made.

\section{REFERENCES}

1. Forbes B, Asgharian B, Dailey LA, Ferguson D, Gerde P, Gumbleton $\mathrm{M}$, et al. Challenges in inhaled product development and opportunities for open innovation. Adv Drug Deliv Rev. 2011;63(1-2):69-87.

2. Gupta V, Thomas G, Ahsan F. Principles and practice of pulmonary drug delivery. In: Narang AS, Mahato RI, editors. Targeted delivery of small and macromolecular drugs. Boca Raton: CRC Press; 2010. p. 371-419.

3. Henning A, Hein S, Schneider M, Bur M, Lehr CM. Pulmonary drug delivery: medicines for inhalation. In: Schäfer-Korting M, editor. Drug delivery. Handbook of experimental pharmacology. 197. Berlin: Springer; 2010. p. 171-92.

4. Taylor G. The absorption and metabolism of xenobiotics in the lung. Adv Drug Deliv Rev. 1990;5(1-2):37-61.

5. Reasor MJ, Hastings KL, Ulrich RG. Drug-induced phospholipidosis: issues and future directions. Expert Opin Drug Saf. 2006;5(4):567-83.

6. de Duve C, de Barsy T, Poole B, Trouet A, Tulkens P, Van Hoof F. Commentary. Lysosomotropic agents. Biochem Pharmacol. 1974;23(18):2495-531.

7. Chu X, Korzekwa K, Elsby R, Fenner K, Galetin A, Lai Y, et al. Intracellular drug concentrations and transporters: measurement, modeling, and implications for the liver. Clin Pharmacol Ther. 2013;94(1):126-41.

8. Logan R, Funk RS, Axcell E, Krise JP. Drug-drug interactions involving lysosomes: mechanisms and potential clinical implications. Expert Opin Drug Metab Toxicol. 2012;8(8):943-58.
9. Logan R, Kong A, Krise JP. Evaluating the roles of autophagy and lysosomal trafficking defects in intracellular distribution-based drug-drug interactions involving lysosomes. J Pharm Sci. 2013;102(11):4173-80.

10. Chen Y, Walsh RJ, Arriaga EA. Selective determination of the doxorubicin content of individual acidic organelles in impure subcellular fractions. Anal Chem. 2005;77(8):2281-7.

11. Duvvuri M, Krise JP. A novel assay reveals that weakly basic model compounds concentrate in lysosomes to an extent greater than $\mathrm{pH}-$ partitioning theory would predict. Mol Pharm. 2005;2(6):440-8.

12. Togami K, Chono S, Morimoto K. Subcellular distribution of azithromycin and clarithromycin in rat alveolar macrophages (NR8383) in vitro. Biol Pharm Bull. 2013;36(9):1494-9.

13. Funk RS, Krise JP. Cationic amphiphilic drugs cause a marked expansion of apparent lysosomal volume: implications for an intracellular distribution-based drug interaction. Mol Pharm. 2012;9(5): 1384-95.

14. Kazmi F, Hensley T, Pope C, Funk RS, Loewen GJ, Buckley DB, et al. Lysosomal sequestration (trapping) of lipophilic amine (cationic amphiphilic) drugs in immortalized human hepatocytes (Fa2N-4 cells). Drug Metab Dispos. 2013;41(4):897-905.

15. Duvvuri M, Gong Y, Chatterji D, Krise JP. Weak base permeability characteristics influence the intracellular sequestration site in the multidrug-resistant human leukemic cell line HL-60. J Biol Chem. 2004;279(31):32367-72.

16. Lemieux B, Percival MD, Falgueyret JP. Quantitation of the lysosomotropic character of cationic amphiphilic drugs using the fluorescent basic amine Red DND-99. Anal Biochem. 2004;327(2): 247-51.

17. Helmke RJ, Boyd RL, German VF, Mangos JA. From growth factor dependence to growth factor responsiveness: the genesis of an alveolar macrophage cell line. In Vitro Cell Dev Biol. 1987;23(8):567-74.

18. Helmke RJ, German VF, Mangos JA. A continuous alveolar macrophage cell line: comparisons with freshly derived alveolar macrophages. In Vitro Cell Dev Biol. 1989;25(1):44-8.

19. Onoshita T, Shimizu Y, Yamaya N, Miyazaki M, Yokoyama M, Fujiwara N, et al. The behavior of PLGA microspheres containing rifampicin in alveolar macrophages. Colloids Surf B: Biointerfaces. 2010;76(1):151-7.

20. Togami K, Chono S, Seki T, Morimoto K. Distribution characteristics of telithromycin, a novel ketolide antimicrobial agent applied for treatment of respiratory infection, in lung epithelial lining fluid and alveolar macrophages. Drug Metab Pharmacokinet. 2009;24(5):41 1-7.

21. McFarland JW, Berger CM, Froshauer SA, Hayashi SF, Hecker SJ, Jaynes BH, et al. Quantitative structure-activity relationships among macrolide antibacterial agents: in vitro and in vivo potency against Pasteurella multocida. J Med Chem. 1997;40(9):1340-6.

22. Ishizaki J, Yokogawa K, Ichimura F, Ohkuma S. Uptake of imipramine in rat liver lysosomes in vitro and its inhibition by basic drugs. J Pharmacol Exp Ther. 2000;294(3):1088-98.

23. Austin RP, Barton P, Cockroft SL, Wenlock MC, Riley RJ. The influence of nonspecific microsomal binding on apparent intrinsic clearance, and its prediction from physicochemical properties. Drug Metab Dispos. 2002;30(12):1497-503.

24. Volgyi G, Ruiz R, Box K, Comer J, Bosch E, Takacs-Novak K. Potentiometric and spectrophotometric pKa determination of water-insoluble compounds: validation study in a new cosolvent system. Anal Chim Acta. 2007;583(2):418-28.

25. Jeppsson AB, Lofdahl CG, Waldeck B, Widmark E. On the predictive value of experiments in vitro in the evaluation of the effect duration of bronchodilator drugs for local administration. Pulm Pharmacol. 1989;2(2):81-5. 
26. Takács-Novák K, Józan M, Szász G. Lipophilicity of amphoteric molecules expressed by the true partition coefficient. Int J Pharm. 1995; 113(1):47-55.

27. Winiwarter S, Bonham NM, Ax F, Hallberg A, Lennernas H, Karlen A. Correlation of human jejunal permeability (in vivo) of drugs with experimentally and theoretically derived parameters. A multivariate data analysis approach. J Med Chem. 1998;41(25): 4939-49.

28. Kerns EH, Di L, Petusky S, Kleintop T, Huryn D, McConnell O, et al. Pharmaceutical profiling method for lipophilicity and integrity using liquid chromatography-mass spectrometry. J Chromatogr B Anal Technol Biomed Life Sci. 2003;791(1-2):381-8.

29. Assandri A, Perazzi A, Berti M. Studies of binding C3-substitute rifamycins to human and bovine serum albumin. J Antibiot (Tokyo). 1977;30(5):409-15.

30. Agrawal S, Panchagnula R. Implication of biopharmaceutics and pharmacokinetics of rifampicin in variable bioavailability from solid oral dosage forms. Biopharm Drug Dispos. 2005;26(8):321-34.

31. Ménochet K, Kenworthy KE, Houston JB, Galetin A. Simultaneous assessment of uptake and metabolism in rat hepatocytes: a comprehensive mechanistic model. J Pharmacol Exp Ther. 2012;341(1):2-15.

32. Cantrill CA, Skinner RA, Rothwell NJ, Penny JI. An immortalised astrocyte cell line maintains the in vivo phenotype of a primary porcine in vitro blood-brain barrier model. Brain Res. 2012;1479:17-30.

33. Cappell KM, Sinnott R, Taus P, Maxfield K, Scarbrough M, Whitehurst AW. Multiple cancer testis antigens function to support tumor cell mitotic fidelity. Mol Cell Biol. 2012;32(20):4131-40.

34. Daniel WA, Wojcikowski J. Contribution of lysosomal trapping to the total tissue uptake of psychotropic drugs. Pharmacol Toxicol. 1997;80(2):62-8.

35. Ohkuma S, Poole B. Fluorescence probe measurement of the intralysosomal $\mathrm{pH}$ in living cells and the perturbation of $\mathrm{pH}$ by various agents. Proc Natl Acad Sci U S A. 1978;75(7):3327-31.

36. Yabe Y, Galetin A, Houston JB. Kinetic characterization of rat hepatic uptake of 16 actively transported drugs. Drug Metab Dispos. 2011;39(10):1808-14.

37. Hallifax D, Houston JB. Uptake and intracellular binding of lipophilic amine drugs by isolated rat hepatocytes and implications for prediction of in vivo metabolic clearance. Drug Metab Dispos. 2006;34(11):1829-36.

38. Togami K, Chono S, Seki T, Morimoto K. Intracellular pharmacokinetics of telithromycin, a ketolide antibiotic, in alveolar macrophages. J Pharm Pharmacol. 2010;62(1):71-5.

39. Hallifax D, Houston JB. Saturable uptake of lipophilic amine drugs into isolated hepatocytes: mechanisms and consequences for quantitative clearance prediction. Drug Metab Dispos. 2007;35(8): 1325-32.

40. Heyneman CA, Reasor MJ. Role of the alveolar macrophage in the induction of pulmonary phospholipidosis by chlorphentermine. II. Drug uptake into cells in vitro. J Pharmacol Exp Ther. 1986;236(1): 60-4.

41. Antonini JM, Reasor MJ. Accumulation of amiodarone and desethylamiodarone by rat alveolar macrophages in cell culture. Biochem Pharmacol. 1991;42(Supplement 1):S151-6.

42. Heyneman CA, Reasor MJ. Role of the alveolar macrophage in the induction of pulmonary phospholipidosis by chlorphentermine. I. Drug and phospholipid levels. J Pharmacol Exp Ther. 1986;236(1): 55-9.

43. Junod AF. Accumulation of 14 G-imipramine in isolated perfused rat lungs. J Pharmacol Exp Ther. 1972;183(1):182-7.

44. Drew R, Siddik ZH, Mimnaugh EG, Gram TE. Species and dose differences in the accumulation of imipramine by mammalian lungs. Drug Metab Dispos. 1981;9(4):322-6.
45. Frezard F, Garnier-Suillerot A. Permeability of lipid bilayer to anthracycline derivatives. Role of the bilayer composition and of the temperature. Biochim Biophys Acta. 1998;1389(1):13-22.

46. Vavricka SR, Van Montfoort J, Ha HR, Meier PJ, Fattinger K. Interactions of rifamycin SV and rifampicin with organic anion uptake systems of human liver. Hepatology. 2002;36(1):164-72.

47. Yamaguchi H, Takeuchi T, Okada M, Kobayashi M, Unno M, Abe $\mathrm{T}$, et al. Screening of antibiotics that interact with organic anion-transporting polypeptides $1 \mathrm{~B} 1$ and 1B3 using fluorescent probes. Biol Pharm Bull. 2011;34(3):389-95.

48. Nakamura T, Nakanishi T, Haruta T, Shirasaka Y, Keogh JP, Tamai I. Transport of ipratropium, an anti-chronic obstructive pulmonary disease drug, is mediated by organic cation/carnitine transporters in human bronchial epithelial cells: implications for carriermediated pulmonary absorption. Mol Pharm. 2010;7(1):187-95.

49. Nakanishi T, Haruta T, Shirasaka Y, Tamai I. Organic cation transporter-mediated renal secretion of ipratropium and tiotropium in rats and humans. Drug Metab Dispos. 201 1;39(1):117-22.

50. Horvath G, Mendes ES, Schmid N, Schmid A, Conner GE, Salathe M, et al. The effect of corticosteroids on the disposal of long-acting beta2-agonists by airway smooth muscle cells. J Allergy Clin Immunol. 2007;120(5):1103-9.

51. Horvath G, Schmid N, Fragoso MA, Schmid A, Conner GE, Salathe M, et al. Epithelial organic cation transporters ensure $\mathrm{pH}$ dependent drug absorption in the airway. Am J Respir Cell Mol Biol. 2007;36(1):53-60.

52. Ishizaki J, Yokogawa K, Hirano M, Nakashima E, Sai Y, Ohkuma $\mathrm{S}$, et al. Contribution of lysosomes to the subcellular distribution of basic drugs in the rat liver. Pharm Res. 1996;13(6):902-6.

53. Joshi UM, Kodavanti PR, Coudert B, Dwyer TM, Mehendale HM. Types of interaction of amphiphilic drugs with phospholipid vesicles. J Pharmacol Exp Ther. 1988;246(1):150-7.

54. Fisar Z, Fuksova K, Velenovska M. Binding of imipramine to phospholipid bilayers using radioligand binding assay. Gen Physiol Biophys. 2004;23(1):77-99.

55. Nadanaciva S, Lu S, Gebhard DF, Jessen BA, Pennie WD, Will Y. A high content screening assay for identifying lysosomotropic compounds. Toxicol In Vitro. 201 1;25(3):715-23.

56. Fischer H, Atzpodien EA, Csato M, Doessegger L, Lenz B, Schmitt $\mathrm{G}$, et al. In silico assay for assessing phospholipidosis potential of small druglike molecules: training, validation, and refinement using several data sets. J Med Chem. 2012;55(1):126-39.

57. Higgins JW, Ke AB, Zamek-Gliszczynski MJ. Clinical CYP3A inhibitor alternatives to ketoconazole, clarithromycin and itraconazole, are not transported into the liver by hepatic organic anion transporting polypeptides and organic cation transporter 1 . Drug Metab Dispos. 2014;42(11):1780-4.

58. Jones HM, Barton HA, Lai Y, Bi YA, Kimoto E, Kempshall S, et al. Mechanistic pharmacokinetic modeling for the prediction of transporter-mediated disposition in humans from sandwich culture human hepatocyte data. Drug Metab Dispos. 2012;40(5):1007-17.

59. Poirier A, Funk C, Scherrmann JM, Lave T. Mechanistic modeling of hepatic transport from cells to whole body: application to napsagatran and fexofenadine. Mol Pharm. 2009;6(6):1716-33.

60. Watanabe T, Kusuhara H, Maeda K, Shitara Y, Sugiyama Y. Physiologically based pharmacokinetic modeling to predict transporter-mediated clearance and distribution of pravastatin in humans. J Pharmacol Exp Ther. 2009;328(2):652-62.

61. Zamek-Gliszczynski MJ, Lee CA, Poirier A, Bentz J, Chu X, Ellens $\mathrm{H}$, et al. ITC recommendations for transporter kinetic parameter estimation and translational modeling of transport-mediated PK and DDIs in humans. Clin Pharmacol Ther. 2013;94(1):64-79. 